Mid-Pacific Marine Laboratory

Annual Report

for the Period

1 October 1977-30 September 1978

Ernst S. Reese

Victor R. Johnson, Jr.

March 1979

Work Performed Under Contract

EY-76-C-08-0703

\title{
University of Hawaii
}

Office of Research Administration

Honolulu, Hawaii 96822

This report NOTICE

sponsored by the United States an account of work

United States nor the IInited Stovinment. Neither the

Energy, nor any of their employees, Department of

contractors, subcontractors, omployees, nor any of their

any warranty, express or or their employees, makes

liability or responsihility implied, or assumes any legal

or usefulness of any infor for the acturacy, completeness

process disclosed, information, apparatus, product or

infringe privately owned rights. 


\section{DISCLAIMER}

This report was prepared as an account of work sponsored by an agency of the United States Government. Neither the United States Government nor any agency Thereof, nor any of their employees, makes any warranty, express or implied, or assumes any legal liability or responsibility for the accuracy, completeness, or usefulness of any information, apparatus, product, or process disclosed, or represents that its use would not infringe privately owned rights. Reference herein to any specific commercial product, process, or service by trade name, trademark, manufacturer, or otherwise does not necessarily constitute or imply its endorsement, recommendation, or favoring by the United States Government or any agency thereof. The views and opinions of authors expressed herein do not necessarily state or reflect those of the United States Government or any agency thereof. 


\section{DISCLAIMER}

Portions of this document may be illegible in electronic image products. Images are produced from the best available original document. 


\section{NOTICE}

This report was prepared to document work sponsored by the United States Government. Neither the United States nor its agent, the United States Department of Energy, nor any federal employees, nor any of their contractors, subcontractors or their employees makes any warranty, expressed or implied, or assumes any legal liability or responsibility for the accuracy, completeness, or usefulness of any information, apparatus, product or process disclosed, or represents that its use would not infringe privately owned rights.

\section{NOTICE}

Reference to a company or product name does not imply approval or recommendation of the product by the University of Hawaii or the U. S. Department of Energy to the exclusion of others that may be suitable.

Printed in the United States of America

Available from:

National Technical Information Service

U. S. Department of Commerce

5285 Port Royal Road

Springfleld, Virginia 22161

Price: Printed Copy $\$ 6.00$

Hicrofiche

$\$ 3.00$ 
NVO/0703-2

Mid-Pacific Marine Laboratory

Annual Report

for the Period

1 October 1977-30 September 1978

Ernst S. Reese

Victor R. Johnson, Jr.

University of Hawaii

Office of Research Administration

Honolulu, Hawaii 96822

Prepared for the

U. S. Department of Energy

Nevada Operations Office

P. O. Box 14100

Las Vegas, Nevada

Under Contract EY-76-C-08-0703 
ANNUAL REPORT FOR FISCAL YEAR 1978

\section{INTRODUCTION}

In January 1978 the Mid-Pacific Marine Laboratory moved into its new facilities, the former Coast Guard buildings located at the northeast end of Enewetak Island. This move highlighted a year of change and increased commitment to the multifaceted dimensions of the Enewetak scene. On the one hand, the laboratory sought to increase its contribution to the scientific understanding of the atoll ecosystem, while, at the same time, responding constructively and energetically to the rapid changes taking place at Enewetak. The laboratory contributed to Operation Clean-up in every way possible including the preparation of an audio-slide show on the natural history of Enewetak Ato 11 . This audio-slide show which stresses the hazards as well as the recreational benefits of the atoll is used in briefing military personnel assigned to duty at Enewetak. Conservation and recreation are central themes of the presentation: enjoy but don't destroy. The laboratory manager prepares the tide chart for the atoll on which all operations are based, and laboratory personnel advise the Defense Nuclear Agency on matters ranging from the reproductive biology of sea birds to the behavior of sharks.

1978 saw many changes in laboratory personnel. By working closely with the lagoon circulation study (Drs. Smith and Stroup) and the hydrogeochemistry study (Dr. Buddemeier), it was possible to hire an additional technician to assist in these programs. This made it possible to have three persons at the laboratory during times of intensive research activity.

A laboratory work boat was acquired which added a dimension of research support heretofore unavailable at. MPML. This boat, a $28 \mathrm{ft}$. mndified fiberglass tunnel hull, met the following criteria: shallow draft, live aboard capability, twin diesel engines for fuel economy and reliability, covered working area for sensitive scientific equipment, and yet small enough to be dry docked at Enewetak for maintenance and safety. It was pulled out of the water and sustained no damage during Typhoon Alice. Presently it is equipped with radio, sonar and radar. Looking ahead to mid 1980 and thereafter, the most up-to-date safety and survival equipment are being ordered. The acquisition of this work boat pin-points a gradual phase-out of high performance, maintenance intensive, gasoline expensive outboard motors in the operation of MPML. The future emphasis will be on dependable, fuel conservative diesel powered work boats. 
Again, looking to the future, 1978 saw the initiation of planning for the appropriate alternate energy technology demonstration center. Working closely with a number of companies, especially Holmes \& Narver, Inc., Mr. Lafayette Young has developed two proposals. The first deals with wind powered water pumping windmills. The second deals with the generation of electricity through the collection of solar energy. The long term goal is to develop a "state-of-the-art" alternate energy demonstration center at Enewetak.

Due to budget cuts in 1978 it was not possible to initiate an "in-house" laboratory research program on mariculture appropriate to the atoll ecosystem and the needs of the Enewetak people. If successful, the program would be equally appropriate to other Marshallese peoples, and in fact, to all other atoll peoples. The program would involve growing giant clams for food and sale of shells. Its success is predicted on the basis of what is known of the biology of these clams and two natural resources of atolls: shallow water and sunlight.

Overall, the Mid-Pacific Marine Laboratory sought to respond productively to the many changes taking place at Enewetak. From comments that have been made to me, it is my impression ( $E$. S. Reese, Director) that we have been successful. The laboratory is playing an active, productive, cooperating role in current activities at Enewetak.

In addition, the laboratory has continued to support a diverse program of research aimed at a better understanding of the atoll ecosystem. Although statistics do not tell the whole story, they are nevertheless informative. During fiscal year 1978, 27 research projects were undertaken at Enewetak involving 81 scientists from 15 universities or laboratories, and amounting to approximately 418 person-weeks of scientific investigation. The number of scientists involved in a project ranged from 1 to 12 , and the duration of trips ranged from 1 to 10 weeks. Although two of the larger projects, the lagoon circulation and the hydrogeochemistry studies, received separate funding from the DOE, they rely on the MPML facility for logistic support. Since these two studies each pay one-third of the salary of a research technician resident at Enewetak, the personweeks of research effort as shown in the table below are underestimated for these projects. All of the other projects are supported fully or in part by MPML. For a more detailed breakdown of the kinds of research projects and the amount of research support devoted to each, please see the table below.

Finally 1978 saw the publication of nine studies carried out at Enewetak during previous years. 
RESEARCH PROJECTS DURING FISCAL YEAR 1978

Research Subject

Number of

Pro- Scien-. Person-

jects Trips tists weeks

Behavior:

Reef fishes: communication,

2

2

5

10

reproduction, sociobiology

Sharks: aggression, hearing,

ultrasonic telemetry

3

3

12

130

Ecology:

Birds: population, reproduction

1

1

1

3

Corals: diversity

1

1

2

4

Crustacea: population, fishery

2

2

4

9

Echinoderms: growth, mortality

1

1

1

2

Fishes: species diversity

1

Molluscs: growth, mortality

1

Rats: population, demography, dosimetry

1

1

3

Geochemistry:

Biogeochemistry: reef organisms

1

1

Hydrogeochemistry: groundwater

1

1

2

Geology:

Bioerosion: sea urchins:

1

1

Calcification: diurnal cycles

Diagenesis: reef plate

1

1

Endolithic processes: biology of

2

Soils: general survey

1

Oceanography:

Lagoon circulation

1

3

12

120 
Research Subject

Number of

Pro- Scien- Person-

jects Trips tists weeks

Physiology:

Corals: symbiosis, zooxanthellae

1

1

2

6

Foraminifera: utilization organic material

1

1

3

6

Sys tematics:

Algae: turf zone

1

1

2

2

General: reference collection

1

2

3

6

Echinoderms: handbook

1

1

2

6

Fishes: blennies, check list

1

1

$I$

2

TOTALS :

27

32

81

418 
(FY78)

(1 Oct 77-30 Sept 78)

(Chronological)

\begin{tabular}{|c|c|c|}
\hline Dates & Investigators & Project \\
\hline $\begin{array}{l}4 \text { Oct. }-14 \text { Dec. } \\
\text { (1977) }\end{array}$ & $\begin{array}{l}\text { Nelson, Donald R. } \\
\text { Allin, R. } \\
\text { Johnson, R. } \\
\text { Mckibben, J. } \\
\text { Nelson, R. } \\
\text { Perkins, Marlin } \\
\text { Pittenger, G. }\end{array}$ & $\begin{array}{l}\text { Social behavior and aggression in } \\
\text { the gray reef shark: studies } \\
\text { using ultrasonic telemetry and } \\
\text { submersible observation. }\end{array}$ \\
\hline $\begin{array}{l}\text { 11-26 Oct. } \\
(1977) \\
\text { 3-25 January } \\
(1978) \\
1 \text { Aug. }-6 \text { Sept. } \\
(1978)\end{array}$ & $\begin{array}{l}\text { Smith, Stephen V. } \\
\text { Stroup, R. } \\
\text { Atkinson, M. } \\
\text { Coleman, J. } \\
\text { Young, R. } \\
\text { Marsh, J. } \\
\text { Schlech, K. } \\
\text { De Costra, M. } \\
\text { Weil, S. } \\
\text { Redalje, R. } \\
\text { Harrison, J. } \\
\text { Werker, M. }\end{array}$ & Lagoon circulation study \\
\hline $\begin{array}{l}\text { 7-23 November } \\
\text { (1977) } \\
21 \text { Mar.-26 Apr. } \\
(1978)\end{array}$ & $\begin{array}{l}\text { Jackson, William B. } \\
\text { Bastian, Robert K. } \\
\text { Denbow, Tom } \\
\text { Temme, Manfred } \\
\text { Vessey, Stephen H. }\end{array}$ & $\begin{array}{l}\text { Ecological investigations of rat } \\
\text { and bird populations on Enewetak } \\
\text { Atoll }\end{array}$ \\
\hline $\begin{array}{l}7-23 \text { November } \\
(1977) \\
25 \cdot \text { Apr } \cdot-10 \text { May } \\
(1978)\end{array}$ & $\begin{array}{l}\text { Randall, John E. } \\
\text { Fielding, Ann } \\
\text { Suzumoto, Arnold } \\
\text { Boolootian, R. }\end{array}$ & $\begin{array}{l}\text { Updating, organization and care } \\
\text { of MPML reference collection }\end{array}$ \\
\hline $\begin{array}{l}29 \text { Nov. }-7 \text { Dec. } \\
(1977) \\
10-29 \text { March } \\
(1978)\end{array}$ & $\begin{array}{l}\text { Buddemeier, Robert } \\
\text { Buddemeier, Dorothy } \\
\text { Goff, S. } \\
\text { Petty, S. } \\
\text { Souza, W. } \\
\text { Tilbrook, B. } \\
\text { Wheatcraft, S. }\end{array}$ & $\begin{array}{l}\text { Hydrogeochemistry of Enewetak } \\
\text { Atoll }\end{array}$ \\
\hline $\begin{array}{l}\text { 14-29 March } \\
\text { (1978) }\end{array}$ & $\begin{array}{l}\text { Baer, Larry } \\
\text { Baer, Christine P. }\end{array}$ & $\begin{array}{l}\text { Communication and dominance anoritg } \\
\text { surgeonfishes }\end{array}$ \\
\hline $\begin{array}{l}\text { 14-29 March } \\
(1978)\end{array}$ & Baer, Christine P. & $\begin{array}{l}\text { Field collection of fish in the } \\
\text { Family Gobiidae }\end{array}$ \\
\hline
\end{tabular}




\begin{tabular}{|c|c|c|}
\hline Dates & Investigators & Project \\
\hline $\begin{array}{l}21 \text { Mar. }-12 \text { Apr. } \\
\text { (1978) }\end{array}$ & Temme, Manfred & Bird populations on Enewetak Atol \\
\hline $\begin{array}{r}2-24 \text { May } \\
(1978)\end{array}$ & $\begin{array}{l}\text { Cierszko, Leon } \\
\text { Cierszko, Esther }\end{array}$ & $\begin{array}{l}\text { Biogeochemistry of coral reef } \\
\text { environments }\end{array}$ \\
\hline $\begin{array}{l}30 \text { May-14 June } \\
(1978)\end{array}$ & $\begin{array}{l}\text { Reese, Ernst S. } \\
\text { Boucher, L. } \\
\text { Motta, P. }\end{array}$ & $\begin{array}{l}\text { Behavioral ecology of coral reef } \\
\text { fishes, especially butterfly- } \\
\text { fishes }\end{array}$ \\
\hline $\begin{array}{l}\text { 9-23 June } \\
\text { (1978) }\end{array}$ & $\begin{array}{l}\text { Smith, Stephen V. } \\
\text { Kinsey, Donald W. } \\
\text { Lewis, Clarke }\end{array}$ & $\begin{array}{l}\text { Diurnal cycles in reef-flat } \\
\text { calcification activity on } \\
\text { Johnston Atoll }\end{array}$ \\
\hline $\begin{array}{c}\text { 13-21 June } \\
\text { (1978) }\end{array}$ & $\begin{array}{l}\text { Atkins, Chet } \\
\text { Jones, Rollie }\end{array}$ & Soil survey for DOE \\
\hline $\begin{array}{l}20 \text { June } 5 \text { July } \\
(1978)\end{array}$ & $\begin{array}{l}\text { Russo, Anthony R. } \\
\text { Akita, Geoff } \\
\text { Riccio, Augustus }\end{array}$ & $\begin{array}{l}\text { Bioerosion by two species of } \\
\text { burrowing sea urchins on Enewetak } \\
\text { Atoll }\end{array}$ \\
\hline $\begin{array}{l}20 \text { June-19 July } \\
\text { (1978) }\end{array}$ & $\begin{array}{l}\text { Silver, Burr A. } \\
\text { Emmendorfer, Alan } \\
\text { Reis, James }\end{array}$ & $\begin{array}{l}\text { Diagenesis and pore evolution } \\
\text { of the reef plate: Enewetak. } \\
\text { Atoll }\end{array}$ \\
\hline $\begin{array}{l}4-26 \text { July } \\
(1978)\end{array}$ & $\begin{array}{l}\text { Gladfelter, William B. } \\
\text { Gladfelter, E. } \\
\text { Ogden, J. }\end{array}$ & $\begin{array}{l}\text { Habitat specificity and compa- } \\
\text { rative composition of tropical } \\
\text { reef fish communities }\end{array}$ \\
\hline $11 \underset{(1978)}{J u 1 y-2}$ A.ug. & Abrams, Peter & $\begin{array}{l}\text { Resource segregation and shell } \\
\text { competition among hermit crabs } \\
\text { at Enewetak }\end{array}$ \\
\hline $\begin{array}{l}25 \text { July-1 Aug. } \\
\text { (1978) }\end{array}$ & $\begin{array}{l}\text { Schlech, Kristen } \\
\text { Atkinson, M. }\end{array}$ & $\begin{array}{l}\text { Observations and identifications } \\
\text { of algal specimens collected } \\
\text { from the seaward turf zones }\end{array}$ \\
\hline $\begin{array}{l}25 \text { July-9 Aug. } \\
\text { (1978) }\end{array}$ & $\begin{array}{l}\text { De Laca, Ted } \\
\text { Hatton, P. } \\
\text { Giannini, A. }\end{array}$ & $\begin{array}{l}\text { Utilization of dissolved and } \\
\text { particulate organic material by } \\
\text { tropical benthic foraminifera }\end{array}$ \\
\hline $\begin{array}{l}25 \text { July-9 Aug. } \\
\text { (1978) }\end{array}$ & $\begin{array}{l}\text { Lipps, Jere } \\
\text { Ronan, T. }\end{array}$ & $\begin{array}{l}\text { Endolithic biology of atolls - } \\
\text { geologic aspects }\end{array}$ \\
\hline $\begin{array}{l}8-23 \text { August } \\
(1978)\end{array}$ & $\begin{array}{l}\text { Stimson, John } \\
\text { Polacheck, T. }\end{array}$ & $\begin{array}{l}\text { Effect of shade on coral reef } \\
\text { community structure }\end{array}$ \\
\hline
\end{tabular}


Dates

15 Aug.-6 Sept. Trench, Robert (1978)
Investigators

Colley, N.
Project

Genetic variability in zooxanthellae and specificity in their symbiosis with reef-dwelling invertebrates

\begin{tabular}{cc}
$\begin{array}{c}12-27 \text { Sept. } \\
(1978)\end{array}$ & Ebert, Tom \\
\hline $\begin{array}{c}12-27 \text { Sept. } \\
(1978)\end{array}$ & $\begin{array}{l}\text { Ford, Richard } \\
\text { Ebert, T. } \\
\text { McCollum, M. }\end{array}$ \\
\hline $\begin{array}{c}12-27 \text { Sept. } \\
(1978)\end{array}$ & Turk, T.
\end{tabular}

Growth and mortality of echinoderms

Population characteristics and fishery potential of spiny lobsters at Enewetak Atoll

Patterns in growth and mortality of marine gastropods at Enewetak Atoll 


\begin{abstract}
Project: Resource segregation and shell competition among hermit crabs at Enewetak

Investigator: Peter A. Abrams

Zoology Department

University of Sydney

Sydney, N.S.W. Australia 2006

Objectives: $\quad 1$. To determine shell and habitat segregation among terrestrial and intertidal hermit crabs.

2. To determine whether shell fighting is a signiflcant factor in interspecific competition among the intertidal crabs.
\end{abstract}

Although at least six species of terrestrial hermit crabs occur in the Indo-Pacific only three have been reported from Enewetak; Coenobita perlatus, C. rugosus and C. brevimanus. These species were studied on Enewetak, Ikuren and Mut Islands. Collections were made to determine size distributions, shell utilization, habitat utilization and relative abundance as well as interspecific overlap. C. perlatus was by far the most abundant species, comprising over $95 \%$ of the individuals collected. Small individuals were most often in Strombus gibberulus gibbosus and Cerithium columna shells, although a wide variety of shells were used. Adults were found almost exclusively in Turbo argyrostoma shells (one individual was collected in a Tonna perdix shell). The populations on Ikuren and Mut had bimodal size distributions. Crabs with weights between 2 and 15 grams were extremely rare, apparently due to the lack of suitably sized shells. The size distribution of the Enewetak population of Coenobita perlatus was not bimodal. There, large juvenile and small adult crabs were found in Vasum turbinellus and Nerita polita shells, as well as tips of Turbo shells. Empty shells which were not severely damaged were essentially absent for all shell size classes on all islands. This is surprising for the case of large Turbo shells on Mut and Ikuren, since the absence of medium sized shells suggests that recruitment to adult size must be a rare occurrence. Shell selection experiments showed that shells occupied by small juvenile Coenobita perlatus were not significantly smaller than the preferred size, while large juvenile and adult crabs were in smaller than the preferred shell size.

C. rugosus is a small crab, and no individuals larger than two grams were found. It occupied the same shell species and habitat as juvenile $C$. perlatus, but was much less abundant. Only three specimens of C. brevimanus were seen during the course of the study. These were three adults collected on Mut. All three occupied. Turbo shells which were in relatively poor condition. They were found in the same habltat as adult $C$. perzatue. 
These results and later observations made at Kwajalein and Guam suggest that there is relatively little interspecific competition among terrestrial hermit crabs due to large scale geographic separation of the species.

The intertidal hermit crab community consisted of the following species: Calcinus seurati, Calcinus laevimanus, Calcinus elagns, Calcinus gaimardi, Calcinus latens, Clibanarius hwomilis, Clibanarius corallinus, Clibanorius sp., Anniculus anniculus and Dardanus lagopodes. Data on habitat and shell overlap was gathered for these species, and will be analyzed later using a computer program developed earlier for estimating relative intensities of inter- and intra-specific competition. The species pairs which appeared to have the strongest interspecific interactions due to resource overlap are: Calcinus seurati and Clibanarius corallinus; Calcinus laevimanus and Clibanarius corallinus; Calcinus elegans and Calcinus latens. Shell release experiments were carried out to determine the significance of habitat partitioning for shell competition. Results suggest that there is relatively little shell movement.

Interspecific shell fighting was studied in the laboratory by two sorts of experiments. In the first, equal numbers of two species were placed in an aquarium with the shells of each species marked differently. These aquaria were monitored over a two to four day period for interspecific shell exchanges. This was done for all of the species pairs with high overlap listed above. No shell exchanges were observed. A second type of experiment was performed in which all of the individuals of one species had their shells modified by breaking off enough of the apex of the shell to expose the crab's abdomen. These were then placed with individuals of the second species which were in intact shells. Concurrently, a similar experiment was carried out in which the roles of the species were reversed. This type of experiment was designed to reveal dominance in shell fighting, but again, virtually no shell exchanges were observed. This suggests that shell fighting is an insignificant component of the total competitive interaction. 
Project: $\quad$ Field collection of fish in the family Gobiidae

Investigator: Christine Baer

Hawaii Institute of Marine Biology

P. 0. Box 1346

Kaneohe, Hawaii 96744

Objectives: $\quad 1$. Work on the Enewetak Fish Reference collection.

2. Collect gobies of the genera Bathygobius and. Cryptocentrus.

Specimens in the fish reference collection were rearranged into alphabetical order by family and under each family alphabetically by genus and then species. Jar top labels and reference collection cards were changed to coincide with the shelf changes.

Many of the specimens were showing signs of "salts" coming out of solution. Whenever this was noticed in any of the jars, the solution, being denatured Ethyl Alcohol, was changed. Denatured Ethyl Alcohol is a very bad medium to use when preserving museum or reference collection specimens. Within $1-1 / 2$ to 2 years the fish turn a uniform brown. It is suggested that the fish collection at MPML be changed to $60 \%$ Isopropyl alcohol.

Many gobies of the genera Bathygobius and Cryptocentmus were collected. Representative specimens were added to the MPML reference collection. Others were returned live to the Hawaii Institute of Marine Biology, Kaneohe, Hawaii, and are presently being used in experiments with gobies of the same species collected in Hawaii. The Enewetak $B$. fuscus are located on sand and are very light while the Hawaiian $B$. fuscus, usually found in lava bottomed tide pools, are almost black.

The gobies are presently kept on a water table with one half black gravel the other half white. The Enewetak and Hawaiian gobies have been placed separately on the water table and allowed to "acclimate." They will be photographed and then switched. to opposite colors. Observed changes in color will be recorded.

Gobies of the genus Cryptocentrus, symbionts with alpheid shrimps, are experimentally being placed with Hawaiian alpheid shrimps of different species than those found normally with Cryptocentrus in the Marshall Islands. The Hawaiian species of alpheid shrimp is normally symbiotic with Psilogobius mainlandi. Partner preference will hopefully be determined among the shrimps and gobies by a series of aquarium studies. 
Project: Communication and dominance among surgeonfishes

\author{
Investigators: Lawrence J. Baer \\ Christine P. Baer \\ Hawaii Institute of Marine Biology \\ P. 0. Box 1.346 \\ Kaneohe, Hawaii 96744
}

Objectives: $\quad$ 1. To observe, quantify and qualify intraspecific and interspecific agonistic communication among fishes of the genus Zebrasoma (family Acanthuridae).

2. To ascertain interspecific dominance within this genus.

Approximately 35 hours were spent in underwater observations. Slightly over 600 intraspecific bouts composed of about 1,200 inter-individual signal-response dyads, were observed and recorded, mostly by Zebrasoma scopas.

Analyses of these signal-response data provided several measures of intraspecific agonistic communication. It was found that the probability of a fish's winning an encounter had a greater effect on how that fish behaved than did the outcome of the bout depend on the actions performed. This indicates that some unrecognized factor also contributed to the ability to win intraspecific encounters. The amount of information traissmitted from the loser to the winner was greater than that transmitted. from the winner to the loser: $0.447 \mathrm{bits} / \mathrm{act}$ vs. $0.157 \mathrm{bits} / \mathrm{act}$. The efficiency of communication was also greater from loser to winner than from winner to loser: $14.6 \%$ vs. $5.8 \%$.

The quality of the important communicative actions differed between winners and losers. For winners, acts which brought them close to other individuals (chasing, swimming up) and aggressive acts (biting) were important, while, for losers, acts which increased distance between fish (withdraw, flee, circle swim) were the important ones.

These results compare favorably, quantitatively and qualitatively, with results obtained through laboratory observations of Hawaiian $Z$. flavescens.

When all signal-response data were pooled, information transmission rose to 0.782 bits/act and efficiency to $24.4 \%$ - higher values than attained by $Z$. flavescens under laboratory conditions.

Several instances of spawning by 2 . scopas were also observed. These spawnings were of similar form to spawnings of 2 . flavescens observed in Hawaii, and were different from published reports concerning other species of acanthurids.

Upon completion of field data collection on Hawailan Z. fluvescens, comparisons to the $Z$. scopas observed in Enewetak will be made to determine the relationship of these species' intraspecific behavior and cominuication when performed under llatuial cunditions. 
Project: $\quad$ Biogeochemistry of coral reef environments

Investigators: Leon S. Ciereszki

Esther M. Ciereszko

Department of Chemistry

University of Oklahoma

Norman, Oklahoma 73019

Objectives:

1. To determine the nature of the chemical substances released into the coral reef environment (a) by secretions of living coral reef organisms, (b) by decomposition of these organisms, and (c) by predators feeding on coral reef coelenterates.

2. To determine the organic constituents of coral reef sediments.

Sediments from a number of locations and the decomposition products of some soft corals and the hard coral Fungia were collected and dried for lipid analyses.

Gut contents of a number of fishes considered to $\bar{f} \in \in \mathbb{d}$ on corals were obtained through the courtesy of Dr. John Randall whose stay at Enewetak overlapped ours by one week. The fish were identified by Dr. Randall: Chaetodon trifasciatus, C. bennetti, C. citrinellus, C. ephippium and Ecsenius bicolor. Preliminary analyses of the gut material indicates the presence of wax, fatty acids and fatty alcohols which are digestion products of waxes. Waxes, such as cetyl palmitate, are normal constituents of corals. The results support the observations made by other workers on the feeding of fishes on corals.

Gut mud was obtained from two parrotfishes and freeze-dried in preparation for lipid analyses.

Mucus was collected from a hard coral Fungia, the soft corals Sarcophyton and Nephthea, the crinoid Comanthus bennetti and the clam Tridacna gigas. Test with benzalkonium chloride reagent suggest the mucoid material in Fungia, Comanthus and Tridacna are polysaccharide sulfates while the mucus from the soft coral gives a negative test for polysaccharide sulfate. It was found that the mucoid could be precipitated from the mucus by the addition of one volume of ethanol $(95 \%)$, and that the mucoid could be isolated as a dry powder by siit table washing at the centrifuge and freeze drying. We have samples of the dry mucus from Nephthea, Fungia and Sarcophyton for chemical study.

Livers from two reef sharks were obtained trom Ur. Kandall. Chemical analysis shows, as expected, that the liver oil of the grey reef shark Carcharhinus amblyrhynchus is rich in squalene, about $50 \%$. 
We were fortunate to obtain unborn young, twins, from two white tip reef sharks. The fetuses were at different stages of development. We intend to compare the lipid composition of the fetuses, particularly that of the liver, with that of the mothers. It is already evident that the lipid content of the livers of the unborn is low compared to that of the adult mothers.

Zooxanthellae were concentrated and freeze dried from two sources: the soft coral Lobophytum and the clam Tridacna gigas. Tridacna mantle was obtained from a large specimen used by Dr. Randall in his studies. Brown body and ovary tissue were also obtained from this clam and freeze dried in preparation for chemical analyses.

Specimens of three soft corals, the crinoid Comanthus and the coral Fungia were freeze dried in preparation for chemical study. 
Project:

Utilization of dissolved and particulate organic material by tropical benthic foraminifera

Investigators: Ted E. De Laca

Peter L. Hatton, Jr.

Albert P. Giannini

Departments of Geology and Chemistry

University of California

Davis, California 95616

Summary of research activities by Principal Investigator, De Laca, not yet received at printing time of this annual report, despite repeated requests by both letter and phone. 
Project: Growth and mortality of echinoderms

Investigator: Thomas A. Ebert

Department of Biology

San Diego State University

San Diego, California 92182

Objective: To determine growth and mortality rates of abundant echinoderms, in particular the sea cucumber Holothuria atra and the slate-pencil urchin Heterocentrotus trigonarius.

Sixty Holothuria atra were collected from the Quarry on Enewetak Island, where animals had been tagged with tetracycline and released one year previous. Of the 60,16 showed clear lines in the planes of the calcareous ring, while others showed evidence of having been tagged (glowing areas in the plates but without clear lines). Growth rate was higher than previously reported for $H$. atra from Ananij Is land (1978 Pac. Sci. 32:183). The Brody-Bertalanffy growth equation for plates (cm) of animals from the Quarry is:

$$
P=0.774\left(1-c^{-0.220 t}\right)
$$

For comparison with Ananij, a typical sized plate of an animal at Ananij is $0.35 \mathrm{~cm}$. The instantaneous growth rate is $0.05 \mathrm{~cm} / \mathrm{yr}$. In the Quarry a similar sized plate would be growing at a rate of $0.09 \mathrm{~cm} / \mathrm{yr}$. The higher growth rate of animals in the Quarry compared with animals at Ananij appears to be the best explanation of their larger size rather than lower mortality rates.

In a continuing attempt to assess frequency of asexual reproduction by transverse fission and rates of regeneration of $H$. atra, $2 \times 2 \mathrm{~m}$ holding pens in the gutter on the seaward side of Ananij Island were constructed. Four pens were stocked as follows:

$$
\begin{aligned}
& \text { Pen 1: } 40 \text { "shorts" - fission products in early stages of } \\
& \text { regeneration } \\
& \text { Pen 2: } 100 \text { large animals, } 19.0 \mathrm{~cm} \pm 3.0 \text { (S.D.) total length } \\
& \text { Pen 3: } 100 \text { small animals, } 9.4 \mathrm{~cm} \pm 1.3 \\
& \text { Pen 4: } 100 \text { medium animals, } 13.7 \mathrm{~cm} \pm 2.0
\end{aligned}
$$

Animals will be measured in April 1979 to obtain an estimate of rates of growth, fission and regeneration. 
A total of 136 Heterocentrotus trigonarius were collected from the area where animals were tagged with tetracycline and released in 1977. Only five animals showed clear marks and all of these were very large individuals. Data are too few to estimate growth.

Finally, 228 Echinometra mathaei were tagged with tetracycline and released in the Sand Island Channel. 
Project: $\quad$ Population characteristics and fishery potential of spiny lobsters at Enewetak Atoll

Investigators: Richard F. Ford

Thomas A. Ebert

Michael McCollum

Department of Biology and

Center for Marine Studies

San Diego State University

San Diego, California 92182

Objectives: 1. To determine basic population characteristics of Panulirus penicillatus, the dominant spiny lobster at Enewetak Atoll.

2. To use this information in evaluating its fishery potential.

3. To obtain lobster samples for analysis of radionuclide levels, in cooperation with Victor Noshkin's research group at the Lawrence Livermore Laboratory.

Panulims penicillatus employs hollowed and eroded coral clumps, conglomerate boulders, and ledges bordering channels for shelter, normally at depths shallower than 4-5 m (George 1972). Our observations and those of others (MacDonald 1971, George 1972) show that juveniles and adults move over the shallow reef flats on the seaward edge of the atoll to feed at night.

Study sites were established on typical reef flats bordering three islands along the northern and eastern sides of the atoll. These are: (1) Enewetak Island, where lobsters are heavily exploited by man, (2) Ananij Island, where there is only limited exploitation, and (3) Enjebi Island where there is now almost no exploitation of lobsters. Sampling was conducted during low tides at night 3-4 times at each sampling site over the period 14-26 September 1978 .

The sex, carapace length (nearest $0.1 \mathrm{~m}$ ), and 1 ive, wet body weight (nearest $1.0 \mathrm{~g}$ ) were determined for each individual in the field. Missing and damaged appendages were noted as an aid in interpreting weight, condition and growth data. The reproductive condition of females also was determined by examining individuals for the presence of new and old spermatophores and extruded eggs in different stages of development. Representative samples of these lobsters from each study site were frozen and sent to Victor Noshkin at the Lawrence Livermore Laboratory for analysis of radionuclides. The remaining lobsters (approximately 200) were marked by two methods and released for continuing mark-recapture studies. A numbered spaghetti anchor tag (Floy FD68B) was inserted into muscle tissue under the posterior dorsal margin of the carapace. Metal punches also were used to make small circular holes in the telson segments. A binary system involving marks at two possible positions on each telson segment was used for coding. 
There was too little time available to conduct adequate recapture sampling. One marked individual was recaptured at Ananij Island. During subsequent sampling in April-May 1979, we hope to recapture animals marked in September to obtain growth data. Additional lobsters will be tagged and recapture samples taken to obtain estimates of population size.

Catch per unit effort data, expressed as the number of lobsters seen and caught per man hour of sampling, are summarized in Table 1. These data indicate that abundance was highest at Ananij Island $(\bar{x}=4.2 /$ man hour), next highest at Enjebi Island (2.7/man hour), and lowest at Enewetak Island (1.4/man hour). Based on the results of a Kruskal-Wallis test, there was no significant difference in catch per unit effort among the three study sites $(p>0.05)$, but there is a definite trend in the data. The lower mean catch per unit effort at Enewetak Island is probably a reflection of both heavy exploitation by man and of the poor tide and wave conditions when we sampled there. The catches were variable at all study sites and, as expected, generally lowest during periods of moonlight, strongest wave action, and of highest low tides where only the upper reef flat was exposed.

The mean carapace length (CL) of male lobsters taken at Enjebi Island was $95.7 \mathrm{~mm}$ (range 59.5-132.0 mm) and for females $81.1 \mathrm{~mm}$ (range $56.0-99.3 \mathrm{~mm}$ ). The mean CL of male lobsters from Ananij was $84.8 \mathrm{~mm}$ (range 51.5-136.4 mm); females had a mean CL of $84.8 \mathrm{~mm}$ (range 46.7-97.9 mm). Individuals from Enewetak Island $(\bar{x}=88.5 \mathrm{~mm}$ $\mathrm{CL}$; range $76.2-100.6 \mathrm{~mm}$ ) were all females. Size-frequency distributions indicate that there were relatively large numbers of individuals of all sizes present in the population. Together with evidence of high densities from the catch per unit effort estimates, this suggests that the population of $P$. penicizzatus on Enewetak Atoll probably would support a reasonably stable fishery by the Enewetakese. We will conduct further studies to evaluate this question more specifically.

Preliminary determinations of length-weight relationships were made for the population, based on all samples combined. The lengthweight relationship for males was $W=1.099 \mathrm{~L}^{2.824}(\mathrm{r}=0.98 ; \mathrm{n}=82)$, that for females without eggs $W=1.455 \mathrm{~L}^{2.713}(\mathrm{r}=0.96 ; \mathrm{n}=67)$, and that for egg bearing females $W=2.118 \mathrm{~L}^{2.576}(\mathrm{r}=0.98 ; \mathrm{n}=70)$.

The sex ratio of lobsters taken at Enjebi Island was 48 males: 54 females ( $1: 1.3$ ), at Ananij Island 36 males:64 females ( $1: 1.8$ ), while at Enewetak Island only females were taken. Results of a chi-square test for independence on these data indicate that there was a significant difference in sex ratios among study sites $(p<0.05)$ with the largest number of males per females at Enjebi Island. The overall sex ratio for all samples combined was 1 male:1.6 female. A similar sex ratio of 1 male: 2 females was réported for this species by MacDonald (1971), based on sampling in Palau. He found that a single large male of ten occupies a coral head with several mature females, suggesting that the observed sex ratios may reflect a mating hierarchy. 
Data concerning numbers of females bearing eggs and those without eggs are summarized in Table 2. The results of a chi-square test for independence indicate that there was a significant difference in numbers of egg bearing females among the three study sites $(p<0.05)$. At Enewetak Island $80 \%$ had eggs, at Ananij Island 55\%, and at Enjebi Island $37 \%$.

However, other results indicate that the numbers of egg bearing females differ significantly with size $\left(\chi^{2}\right.$ test; $\left.p<0.05\right)$. Of all females $<70.0 \mathrm{~mm}$ CL only $18 \%$ had eggs, of those $70.1-80.0 \mathrm{~mm} \mathrm{CL} 70 \%$ had eggs, and of those $80.1-90,0 \mathrm{~mm}$ and $>90.1 \mathrm{~mm}$ CL $54 \%$ and $53 \%$, respectively, were carrying eggs. The results of a Kruskal-Wallis test indicate that there was a significant difference in size among sites $(p<0.05)$. The difference appears to be due primarily to the lack of small individuals from Enewetak.

The significance of these data on reproductive condition is unclear because of these complicating factors. However, evidence concerning differences in:sex ratios and number of egg bearing females may reflect differences in environmental conditions at the three study sites. This will be investigated further.

It was observed that females tended to occur farther inshore on the reef flats. During sampling periods at Enewetak and Ananij Islands when night low tides were relatively high, we encountered only or predominantly females on the inner part of the reef flats. This preliminary evidence suggests that females may tend to segregate from males while foraging on the reef flat. 
Table 1. Catch per unit effort data for Panulims penicizlatus at Encwetak $\Lambda$ toll, 1/1-26 September 1978

\begin{tabular}{|c|c|c|c|c|c|}
\hline $\begin{array}{l}\text { Sampling } \\
\text { Date }\end{array}$ & $\begin{array}{l}\text { Study } \\
\text { Site }\end{array}$ & $\begin{array}{l}\text { Persons } \\
\text { Sampling }\end{array}$ & $\begin{array}{c}\text { Hours } \\
\text { Sampled }\end{array}$ & $\begin{array}{c}\text { Lobsters } \\
\text { Caught \& } \\
\text { Seen }\end{array}$ & $\begin{array}{l}\text { Lobsters } \\
\text { per } \\
\text { Man Hour }\end{array}$ \\
\hline $\begin{array}{l}9 / 14 \\
9 / 15 \\
9 / 17 \\
9 / 21\end{array}$ & $\begin{array}{l}\text { Ananij Is. } \\
\text { Ananij Is. } \\
\text { Ananij Is. } \\
\text { Ananij Is. }\end{array}$ & $\begin{array}{l}4 \\
4 \\
4 \\
3\end{array}$ & $\begin{array}{l}2 \\
2 \\
2 \\
2\end{array}$ & $\begin{array}{r}3 \\
56 \\
23 \\
39\end{array}$ & $\begin{array}{r}0.4 \\
7.0 \\
2.9 \\
\bar{x}=4.2\end{array}$ \\
\hline $\begin{array}{l}9 / 18 \\
9 / 19 \\
9 / 20\end{array}$ & $\begin{array}{l}\text { Enjebi Is. } \\
\text { Enjebi Is. } \\
\text { Enjebi Is. }\end{array}$ & $\begin{array}{l}6 \\
5 \\
5\end{array}$ & $\begin{array}{l}2 \\
4 \\
3\end{array}$ & $\begin{array}{l}44 \\
48 \\
28\end{array}$ & $\begin{array}{r}3.7 \\
2.4 \\
1.9 \\
\bar{x}=2.7\end{array}$ \\
\hline $\begin{array}{l}9 / 23 \\
9 / 25 \\
9 / 26\end{array}$ & $\begin{array}{l}\text { Enewe tak Is. } \\
\text { Enewetak Is. } \\
\text { Enewetak Is. }\end{array}$ & $\begin{array}{l}3 \\
3 \\
2\end{array}$ & $\begin{array}{l}2 \\
2.5 \\
1\end{array}$ & $\begin{array}{l}8 \\
9 \\
0\end{array}$ & $\begin{array}{l}3.0 \\
1.2 \\
0 \\
\bar{x}=1.4\end{array}$ \\
\hline
\end{tabular}

Table 2. Reproductive condition of female Panulimus penicillatus from three study sites at Enewetak Atoll.

\begin{tabular}{|c|c|c|c|c|}
\hline \multirow[t]{2}{*}{. } & \multicolumn{2}{|c|}{ Reproductive Condition } & \multirow[b]{2}{*}{ Totals } & \multirow[b]{2}{*}{$\%$ With Eggs } \\
\hline & Eggs & Without Eggs & & \\
\hline Enewe tak Is. & 16 & 4 & 20 & 80 \\
\hline Ananij Is. & 35 & 29 & 64 & 55 \\
\hline Enjebi Is. & 20 & 34 & 54 & 37 \\
\hline Totals & 71 & 67 & 138 & \\
\hline
\end{tabular}


Project: Habitat specificity and comparative composition of tropical reef fish communities

Investigators: William B. Gladfelter

John C. Ogden

Elizabeth H. Gladfelter

West Indies Laboratory

Fairleigh Dickinson University

Christiansted, St. Croix, U.S. Virgin Islands 00820

Objectives:

1. To census the fish communities of a number of medium-sized shallow-water patch reefs with the goal of determining basic community parameters principally diversity, community similarity and trophic structure.

2. To compare these results with the results of similar censuses carried out on a comparable series of patch reefs in the Caribbean.

3. To account for significant differences in community structure between the two regions.

Fifteen shallow-water patch reefs (mean projected area $=170 \mathrm{~m}^{2}$ ) lying on the lagoonal shelf between Enewetak and Aniyaanii Islands were censused. All reefs were censused twiced. During each census the number of individuals in each of three size classes (small, medium, large) was recorded for each species by each observer. Immediately after the census, data of the three censuses were combined. At the. end of the census period, the reefs were photographed from the air, sketched underwater, measured along two axes and generally characterized in terms of structure. Identification of most fishes was carried out visually using principally two references: Coastal Fishes of Southern Japan and Pacific Marine Fishes (Vols. 1, 5, 6). Species difficult to identify in the field were speared for confirmation.

Analysis of the data is still in progress. Diversity has been determined in terms of species number on each reef, and using the Shannon-Wiener index for diversity. Similarity between the faunas of all pairs of reefs was determined as done by Gladfelter and Gladfelter (1978). Trophic categories of the fishes were determined using the data presented in Hobson (1974) and Hiatt and Strasburg (1960); many extrapolations were necessary and these results can only be taken as approximate.

Some of the relevant community parameters have been summarized below in Table 1, along with comparative data from the Atlantic (St. Croix): 
Table 1

\begin{tabular}{|c|c|c|c|c|c|c|c|c|}
\hline & & & $\begin{array}{c}\text { No. } \\
\text { Species }\end{array}$ & $\begin{array}{c}\text { No. } \\
\text { Individuals }\end{array}$ & $\mathrm{H}^{\prime}$ & $\mathrm{J}^{\prime}$ & Similarity & Reef Area \\
\hline \multirow{3}{*}{$\begin{array}{l}\text { St. Croix } \\
\text { (Atlantic) }\end{array}$} & Total & & 116 & - & - & - & - & $(26,000)$ \\
\hline & Mean & & 64 & 951 & 1.45 & .81 & .73 & $(2,000)$ \\
\hline & Range & $\begin{array}{l}(\min ) \\
(\max )\end{array}$ & $\begin{array}{l}52 \\
80\end{array}$ & $\begin{array}{r}573 \\
1,180\end{array}$ & $\begin{array}{l}1.39 \\
1.55\end{array}$ & $\begin{array}{l}.77 \\
.82\end{array}$ & $\begin{array}{l}.65 \\
.81\end{array}$ & $\begin{array}{l}(300) \\
(4,600)\end{array}$ \\
\hline \multirow{3}{*}{$\begin{array}{l}\text { Enewetak } \\
\text { (Pacific) }\end{array}$} & Total & & 187 & - & - & - & - & 2,600 \\
\hline & Mean & & 93 & 651 & 1.62 & .82 & .61 & 170 \\
\hline & Range & $\begin{array}{l}(\min ) \\
(\max )\end{array}$ & $\begin{array}{r}71 \\
110\end{array}$ & $\begin{array}{l}437 \\
936\end{array}$ & $\begin{array}{l}1.48 \\
1.71\end{array}$ & $\begin{array}{l}.77 \\
.87\end{array}$ & $\begin{array}{l}.46 \\
.81\end{array}$ & $\begin{array}{r}90 \\
350\end{array}$ \\
\hline
\end{tabular}

En Table 1, $\mathrm{H}^{\prime}=$ Shannon-Wiener diversity index; $\mathrm{J}^{\prime}=$ equitability, Reef areas for St. Croix are given ior the reef slope and the slope + flat (in parentheses). Trophic categories have been summarized below in Table 2: 
Table 2

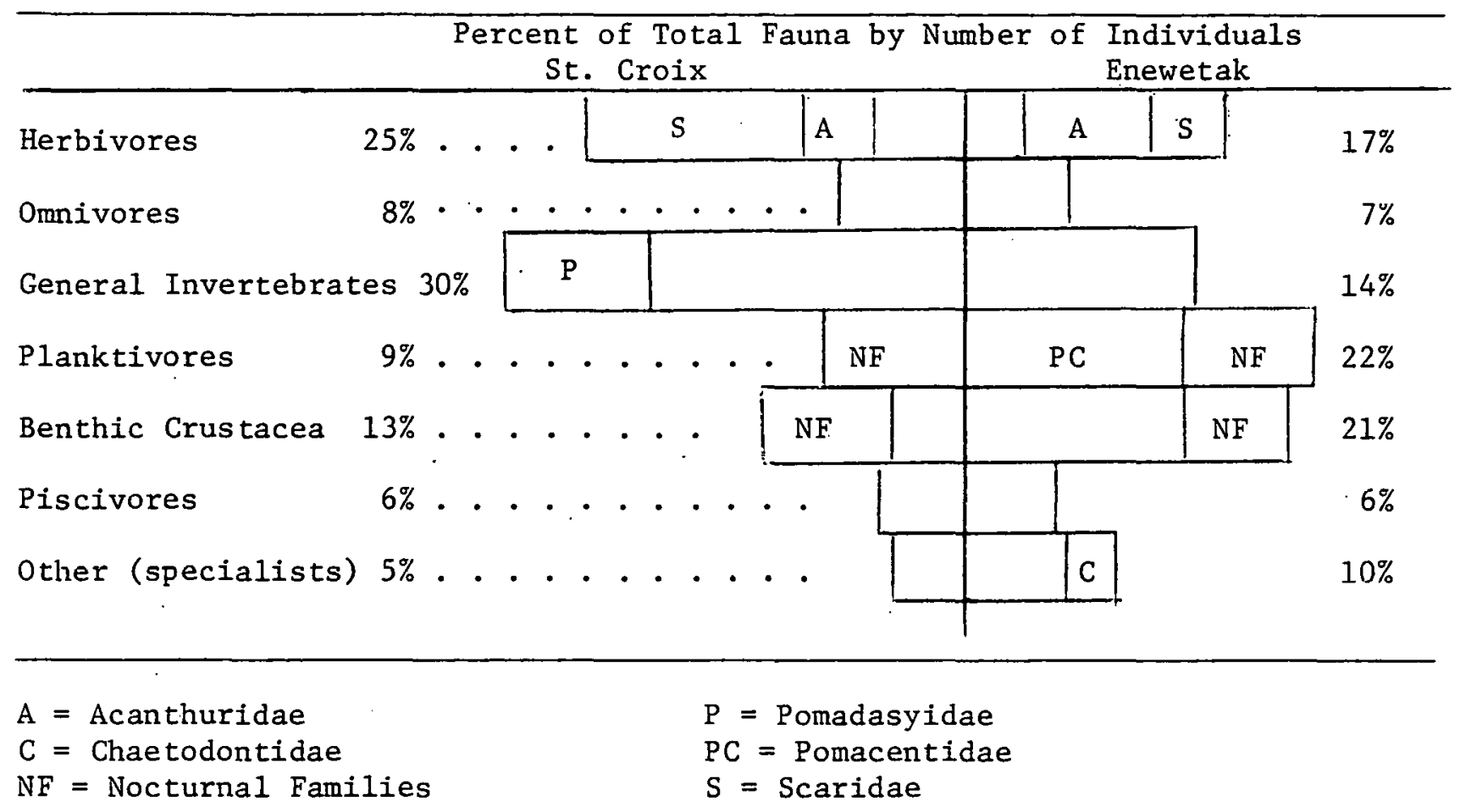

To summarize:

1. Diversity (no. of species or $\mathrm{H}^{\prime}$ ) is greater on Pacific reefs at the species level.

2. Diversity at the family level is greater in the Atlantic study area (37 families on St. Croix vs. 31 families at Enewetak, despite the larger no. of species).

3. The lower diversity of families at Enewetak reflects the greater species diversity within families there (e.g., 40 spp. of Labridae vs. 7 at St. (roix).

4. Fish density (no. individuals per unit area) is greater at Enewetak, but this may reflect lower fishing pressure.

5. The mean similarity between the faunas of all pairs of reefs is significantly lower at Enewetak (student's t-test, p<.001). This tends to corroborate the views of Sale (1977, and others), but the similarity is not as low as expected based on the findings from isolated coral heads or block structures.

6. Most of the differences in trophic composition of the two faunas is probably due to different availabilities of food (not generally. investigated, but this is true in the case of diurnal planktivores [1\% at St. Croix vs. 14\% at Enewetak]). Many of the differences can be accounted for by the greater abundance of one or a few families in those categories which differ greatly (e.g., Pomadasyidae in St. Croix, coralivorous Chaetodontidae at Enewetak). 


\begin{abstract}
Project: Ecological investigations of rat and bird populations on Enewetak Atoll

Investigators: William B. Jackson

Robert K. Bastian

Manfred Temme

Tom Denbow

Stephen H. Vessey

Environmental Studies Center

Bowling Green State University

Bowling Green, Ohio 43403

Objectives: $\quad$ 1. Observations on rat and bird populations in

relationship to Operation Clean-up.

2. Implantation of dosimeters in roof and Polynesian rats.

3. Recapture of implanted rats and subsequent analysis of their potential usefulness as environmental monitors.
\end{abstract}

\title{
INTRODUCTION
}

Rodents are the only non-human (except for feral cats and pet dogs) mammals at Enewetak Atoll. Two species, Rattus exulans and $R$. rattus, live allopatrically on the islets. Dosimeters, implanted under their skin could, because of the rats' omnivorous food habits and close contact with the terrestrial environment, allow the rats to serve as living environmental monitors.

The dosimeters, developed by ERDA, consist of a small ( $\sim \mathrm{Im}$ diameter) flat, plastic capsule, resembling a cold tablet, containing a small calcium-fluoride chip. Implants were made in the area between the shoulder blades of the rats. The animals, which were caught alive, were held with gloves while the guard hairs and underfur were clipped with sharp scissors. A small incision was made into the skin of the unanaesthetized animal. With a hemostat a small subcutaneous pocket was formed, the dosimeter inserted, and the cut closed with two or three stitches of cat gut suture material. Holding the unanaesthetized animal with gloves saved time, did not stress the animal too much, and was easy to carry out in the field. Alcohol was used to maintain somewhat sterile working conditions.

\section{CUNDITIUN UF THE ATULL IN RELATION TO THE CLEANUP OPERATION}

At the time of arrival on the atoll on 7 November 1977, troops were stationed on both Enewetak and Lojwa islets, along with boats and various other support vehicles. 
The presence of the military facilitated the dosimeter implantation work considerably, since in addition to the usual support provided by the MPML, transport of traps and equipment to other islets was frequently possible on military vessels.

\section{INFORMATION ON THE CONDITION IN NOVEMBER 1977 OF EACH ISLET VISITED}

Islet ENJEBI (Janet): Most vegetation had been cleared away by bulldozers and pushed up into long rows and piles. The intention is to burn this material after drying to make room for planting coconut trees. However, since most of the root systems are still in contact with the soil, the woody brush dries only partially; and many stalks of Scaevola and Messerschmidia resprouted. A narrow strip of Scaevola and Messerschmidia is usually left around the island to serve as a windbreak. Several clumps of large vegetation remained, especially around the experimental farm area.

In the bare areas between the brush piles low vegetation is growing vigorously, supported by the frequent rainfalls, especially prior to our arrival. These are especially the grasses, probably Fimbristyllis sp., Lepturus sp., and the two species of Morning Glory. While Ipomoea pescaprae grows over the entire islet, I. tuba grows in patches in the northern parts of the island and prefers to climb as a epiphyte on Messerschmidia and Scaevola.

At the time of the visit there was little human disturbance on the islet. Only four persons are stationed here, living in a trailer. Bird life is still relatively abundant. Noddies (Anous stolidus) breed singly and on slightly elevated brush and soil piles. The higher vegetation around the island is inhabited by White Terns (Gygis alba) and Anous tenuirostris.

The created open areas are used as resting and feeding places by Turnstones, Golden Plovers, and Bristle-thighed Curlews. The coral-sandy beaches are visited by Black-naped Terns and the coral rock shelves by Reef Herons, Turnstones, and one Whimbrel. One pair of White-tailed Tropicbirds flew over the island. Later a military officer reported that he had seen a pair under bushes, apparently breeding. Along the shoreline, numerous Sooty Terns were observed to pass by, and occasional Crested Terns were noted also.

The rat population seems still relatively high but appears to be, because of the bulldozing, somewhat scattered and difficult to trap. Rats are living in the brush and soil piles, and were trapped there. However, in some open areas trapping success was equally high. Two trapping nights (with running the trap lines a second time each night) yielded 45 rats ( $R$. rattus). All rats, in comparison with $R$. rattus from Runit and Ananij, appeared to be relatively small. There were no restrictions in regard to our free movements on the islet. 
Islet complex Lojwa-Bijire-Aomon (Ursula-Tilda-Sally): LOJWA is almost entirely stripped of vegetation, except for a few bushes of Scaevola and Messerschmidia at the outer areas of the islet. Lojwa serves as a second base for the military clean-up operations with approximately 200 people. Heavy equipment like big trucks, cranes, bulldozers, and tank vehicles are plentiful. Numerous temporary houses have been erected.

Except for a few Turnstones and Reef Herons at the beach, no birdlife was found on the islet. Rats ( $R$. exulans) seem still to be around. According to the military, a rat control program is being started.

BIJIRE is halfway cleared of vegetation, the SE side up to the landing strip. The NW side of the air strip was declared a "bird sanctuary" and was not touched by bulldozers.

Wedge-tailed Shearwaters (Puffinus pacificus) were not previously considered resident in the Enewetak Atoll, but two specimens had been previously collected (Carpenter, et al., 1968). In the NW portion of the islet a sizeable colony of this species was found. Numerous holes, dug by the birds themselves in the soft sand, were found. Looking into the dark entrances 18 to 20 young birds were counted during the day time. Some holes were checked out by placing the hand inside and found empty. Other burrows were continuous and had two entrances. Some burrows were very deep and bent so that the young were not visible. At night, when the colony was active, Bastian estimated 50 breeding pairs. Most young birds were almost ready to leave the colony. Military personnel reported having seen this colony a year before in November 1976.

Rats ( $R$. exulans) are still abundant in this portion of this island. In one night 40 specimens were caught and dosimeters implanted.

On AOMON military personnel were working at the time of the visits (November $9,14,15,21$ ). Trapping of $R$. exulans was done at the NW side of the islet (Figure 2) for one night. Dosimeters were implanted into 21 specimens.

Also on this island, bird observations were only incidental to the rat work, which took most of the available and restricted times. However, interesting bird species were seen at several small freshwater (standing rain water) ponds on November 9.

One Wood Sandpiper (Tringa glareola), an accidental and probably the first record for the total Marshall Islands, rested here. In addition, 12 Sharp-tailed Sandpipers (Calidris acuminata) were found in the company of a few Turnstones and Pacific Golden Plovers. Most of the same species were seen on November 21; again the presence of the Wood Sandpiper confirmed.

It was possible to observe sporadically the founding of the breeding colony of Sooty Terns (Stema fuscata). On the first visit (November 9) 150 Sooty Terns were seen circling high in the sky above the islet. On 
November 14 a breeding ground was found (Figure 2). The next day the colony had enlarged toward East, and on November 21 another large area $(\sim 80 \times 120 \mathrm{~m})$ was occupied by the birds. This area was largely the bare sandy swath left by bulldozers as one of the sampling grid line. Distances between nests, containing only one egg, were estimated to average $0.5 \mathrm{~m}$, with a range of $0.28-1.50 \mathrm{~m}$. Often the density was one to four nests $/ \mathrm{m}^{2}$. Some behavioral observations were made comparing reproductive and aggressive postures and signals with those of four other tern species studied earlier. Rough estimates indicated that about 5,000 breeding pairs were present in the colony.

Bastian caught 25 banded specimens. Two heads were brought back to Bowling Green, and one was found to be infested with nasal mites. Restriction of movements and lack of time did not allow a more extensive survey of bird populations on this islet.

Islet IKUREN (Glenn): The islet Ikuren was visited on November 12 , to trap Polynesian rats to serve as a reference population. The party stayed overnight and left the next day.

The islet is undisturbed and the vegetation largely is made up of Pisonia, Messerschmidia, Cocos and Scaevola communities. Numerous Hermit crabs (several species) and Coconut crabs were seen. The one night of trapping resulted in the capture of $21 R$. exulans.

Islet ANANIJ (Bruce): Islet Ananij is undisturbed by human activity except for occasional picnics on Sundays. An empty truck and one large black plastic sheet are there, apparently to provide shelter for the people.

The interior of the small forest consists of Pisonia trees and a few Messerschmidia trees, which reach a height of $5 \mathrm{~m}$; the fringe of the islet are covered by the pionier shrub species Scaevola and Messerschmidia. A few coconut trees are found in the interior. Large numbers of fallen and rotting coconuts were lying under the trees. Many of them showed signs of having been opened by rats; a few were sprouting. The islet was approached from the lagoon side by boat, which was anchored at the center of the islet, where the camp was established. Left and right from the camp rats were caught under Pisonia trees in a circle of approximately $250 \mathrm{~m}$ diameter. The trap lines were run at 21:30 $\mathrm{h}$ again. Implantation was done immediately after trapping (until $0300 \mathrm{~h}$ ). At $0600 \mathrm{~h}$ the trap lines were checked again; the total catch was 36 specimens. Implanting continued until noon. These implanted rats and this islet serve as a reference for $R$. rattus.

Islet RUNIT (Yvonne): Although only one night was available for trapping with an additional run of the trap lines at $2200 \mathrm{~h}$, "a total of 22 animals was caught and dosimeters implanted. A military vehicle was provided and facilitated the work tremendously. Overnight the party of four slept in the shelter 
not far from the pier. At noon of November 17, the islet was left and the party returned to Enewetak. Near the pier construction of a few new wooden units was underway, and at several sites the island has been cleared of vegetation by bulldozers.

\section{BIRD ACCOUNTS BY SPECIES FROM NOVEMBER 1977 VISIT}

Puffinus pacificus: Amerson (1969) cites breeding records of this species from the Marshalls - Taongi, Bikar and Takar. Other sites: Enewetak, Bikini, Rongerik, Rongelap, Jaluit remain still with a question mark. This species has been recorded as a wanderer but not a resident of the Enewetak Atoll. Two specimens were collected and remain in the BGSU collection (Carpenter et al., 1968; Amerson, 1969). On the visit to Bijire islet a breeding colony was found in the midst of a large Messerschmidia growth. Over 50 burrow entrances were counted, apparently dug by the birds themselves into the relatively loose, darkened coral sand. During daytime about 20 young birds, almost ready to leave their burrows were counted. Not all burrows were occupied, as determined by inserting the arm into them. Some burrows were shallow, and the end could be reached. Others were so deep that the young were able to hide completely. At night when the colony was active Bastian estimated the colony to consist of about 50 pairs.

In conversations with some military officers, it was learned that this colony had been known to exist earlier in the year. That this colony had not been found earlier by some of the research teams is perhaps due to the time of the year when the islets were visited. Most teams are at Enewetak in spring or summer; apparently this site is not occupied at that time.

Phaethon mubricauda: Only two birds were seen on Bijire islet on November 14, flying over the island toward SE.

Phaeton lepturus: This species was more of ten seen than the preceding one. 'Iwice one pair flew across Enjebi. Later reports given by military men indicated a possibility of breeding on the islet. Three White-tailed Tropicbirds were seen flying over Ikuren.

Sula sula: While waiting at the pier early morning of November 9 on Enewetak, we saw one Red-footed Booby flying among four Brown Boobies, passing the islet, and heading in the $\mathrm{NE}$ direction.

Sula Zeucogaster: As mentioned under Sula sula, four specimens of this species passed Enewetak and headed into a NE direction. Three more Brown Boobies were seen early November 13 on Ikuren, also heading NE.

Fregata minor: A total of six birds were seen flying over different islets: Bijire (3), Enewetak (2) and Ikuren (1).

Stema sumatrana: At several locations in the Atoll Black-naped Terns were seen. In most instances they were adult birds with one fledged young. The birds either flew over water or rested on posts or bunker parts lying imbedded in the beach; some were resting on the ferrocement ship near the deep entrance. 
Stema fuscata: The founding of a breeding colony of approximately 5,000 Sooty Terns was observed during the stay on the Enewetak Atoll. On the first visit (November 9) to the Lojwa-Bijire-Aomon complex about 150 Sooty Terns were noted circling high in the sky. This did not arouse any suspicion of colony establishment. On November 12, however, passing by the islet complex on the way to Ikuren, I noted a dense flock of this species close to the ground at the northwestern tip of Aomon.

On November 14, the colony was visited and approximately 1,000 pairs had already settled on a grassy area surrounded by Messerschmidia and Scaevola shrubs (Section $I$ on map). The following day more birds had laid eggs, and the colony had expanded wastward into a more open and sandy area (Section II). When the islet was visited again on November 21 , the colony had enlarged tremendously and occupied the loose coral sand area (Section III), which had been cleared of brush by bulldozers the week before. It is estimated that about 5,000 pairs were present at this time.

Section I was checked and numerous eggs were found opened and destroyed; and this part of the colony had been greatly thinned out. This damage possibly could have been inflicted by rats ( $R$. exulans). Bastian caught 25 Sooty Tern which were banded and noted the band numbers. Heads of two specimens were brought back to Bowling Green; one was found to be positive for nasal mites. As far as the brief observation periods permitted, distances between nests were estimated, and some reproductive behavior was observed. Some of the behavior patterns are similar to those of Sterna himundo and $S$. macmurus, which do not breed in such close proximity, and quite dissimilar to $S$. sandvicensis, which also breeds as close as $S$. fuscata.

Sterna bergii: As in previous years (Carpenter et al., 1968) Sterna bergi $i$ was seen occasionally either flying by or at some of the islets. The characteristic call was often heard at Enjebi (November 10), when six birds passed the islet and headed southeastward. Nine birds were seen resting, as in several places in the Philippines (pers. obs.), on post rows quite some distances from the island. Three birds, among them one adult with one fledged young, were noted at Ikuren.

Anous stolidus: No large aggregations or breeding colonies were found, as had been seen in some previous years (Woodbury, 1962; Carpenter et al., 1968). On most islands visited occasional nests were found, containing only eggs at this time of the year. One nest found on Enjebi was located on dried brush at a height of $50 \mathrm{~cm}$. On the north-rim of Runit about ten pairs were found breeding closely together, with nests being approximately 2 to $3 \mathrm{~m}$ apart. Common Noddies were found flying about on islets or were seen fishing in flocks of 30 to 60 individuals, at times together with $A$. tenuirostris. When schools of small fish were driven to the water surfaces by predator fish and leaped out of the water, Noddy Terns aggregated and plunged down to take the small prey. Occasionally a few Black-naped Terns were among these flocks. While on Ikuren, between 0700 and $0730 \mathrm{~h}$ numerous Noddy Terns flew across the 
island in a SE direction. The passing groups were estimated to consist of about $80 \%$ of $A$. tenuirostris. A. stolidus was not as common as the following species; however, lack of time prevented a closer investigation.

A. tenuirostris: It appeared that on most islands visited this species was the one more commonly seen at this time of the year. Only a few nests were seen incidentally to rodent work. One nest on Ikurin contained one egg. On Bijire one large chick sat on a nest, and on Ananij one adult was incubating one egg. Circling birds on several islets indicated that they likely had nests, but at this time no major breeding season seems to prevail. Estimates in Table 1 also include birds seen moving about and are not restricted to breeding birds. Most nests discovered were located in large Messerschmidia trees.

Gygis alba: Most White Terns seen seemed to be involved in breeding or rearing young. On Ikuren several eggs were seen on bare limbs. Due to lack of time no intensive search could be made for details of breeding activities. However, the number of birds in Table 1 indicates estimates of birds involved in breeding. No chicks were seen, but calls indicated the presence of young. Breeding also was indicated by the anti-predatory behavior of the adults. When the forest was entered for rat work, birds showed a considerable excitement, and often adults hovered closely over the intruder.

Egretta sacra: Reef herons were seen on coral reefs or flying by at several islets (Table 1 ). Of 13 herons noted, five were gray ( $38.5 \%)$ and each of four were either mottled or white $(30.8 \%)$. Often either one white or a mottled specimen was seen flying in company of a gray bird.

Anas sp.: On Aomon, Bastian reported having seen three ducks but was not able to identify them to species.

Pluvialis dominica fulva: Almost every islet visited had populations of this species. It is very numerous on the larger islets which have wider open and flat areas, such as grasslands, airstrips, bulldozed clearings (Enjebi) and extensive coral flats (Table 1). The taxiways of the airstrip on Enewetak were a common. resting place during high tides. The birds often were found in association with Ruddy Turnstones.

Charadrius mongolus: The Mongolian Dotterel has been reported from the Marshall Islands only from the Mayuro and Jaluit Atolls and is considered as an uncommon migrant to the Marshall Islands (Amerson, 1969). One specimen was seen on Enewetak islet on November 20, and again met with later on the same day at the taxiway of the Enewetak airstrip. During low tide the bird was seen in loose company with several Turnstones, Golden Plovers, and one Bartailed Godwit. Occasionally the bird was chased by a Golden Piover. This species has not been reported from this atoll (Woodbury, 1962; Carpenter et al., 1968), and this represents a first sight record. 
Numenius phaeopus: The occurrence of this species seems to fluctuate. While Carpetner et al. (1968) did not notice a Whimbrel at all, Johnson (1973) found more Whimbrels than Bristle-thighed Curlew during the boreal summer. During this expedition only three Whimbrels were heard or seen: one each on Enjebi, Enewetak and Ikuren. The calls, totally different from the calls of $N$. tahitiensis, made correct identification simple. Whimbrels were usually found less frequently than $N$. tahitiensis on the islets but more commonly on rocky coral flats. The one observed on Enewetak, on coral flats during low tide, was seen during high tide on the airstrip later that day.

Numenius tahitiensis: This species was often met with on grassy plains on islets and was especially common on the larger islet, Enjebi. Clearing the island of vegetation by bulldozing apparently had some enhancing effect on the presence of this species. Often birds were seen perching on large bare limbs or on coral sand piles which had been pushed up by bulldozing. In several instances this species was seen in display flight uttering long calls.

Limosa Zapponica: This species has been seen twice earlier on the Enewetak Atoll (Pearson and Knudsen, 1967; Carpenter et al., 1968). One specimen was observed on the coral flats in the morning of November 20, at the ocean side of Enewetak islet. Later on the same day the bird rested during high tide on the taxiway of the airfield.

Tringa glareola: So far this species has been reported only from western Micronesia. In Guam and Marianas it is considered as an uncommon visitor. On Palau, however, it is a regular migrant (Baker, 1951; Mayr, 1945). One specimen was met with on Enewetak Atoll islet Aomon on November 9 in one of the many small freshwater ponds. Here the bird was in company of 12 Sharp-tailed Sandpipers, a few Golden Plovers, and some Ruddy Turnstones. The bird was seen again on a subsequent visit to the islet on November 21 , and the characteristic call was heard. This accidental may have reached the atoll from the west. In Southeast Asia this species is a very common migrant and has been reported also in great numbers from the Philippines (Mayr, 1946; DuPont, 1971; Temme, 1974). This is the first sight record for the Marshall Islands.

Heteroscelus incanum: This species is a very common migrant and was seen on almost each islet in varying numbers. Its presence was associated with rocky coral flats. In case no specimens are indicated in Table 1, lack of time was probably the reason for not recording this species on the respective islets.

Arenaria interpres: The same explanation of not finding this species on all islets as given for the former species is true for this one. The Ruddy Turnstone is also a very common species on most of the islets. In contrast to the Tattler, Turnstones are found not only at rocky and sandy beaches but also on grassy plains and other areas clear of vegetation. During high tide many birds were seen on the taxiway of the air-strip on Enewetak. Turnstones visit freshwater ponds, as on the islet of Aomon. 


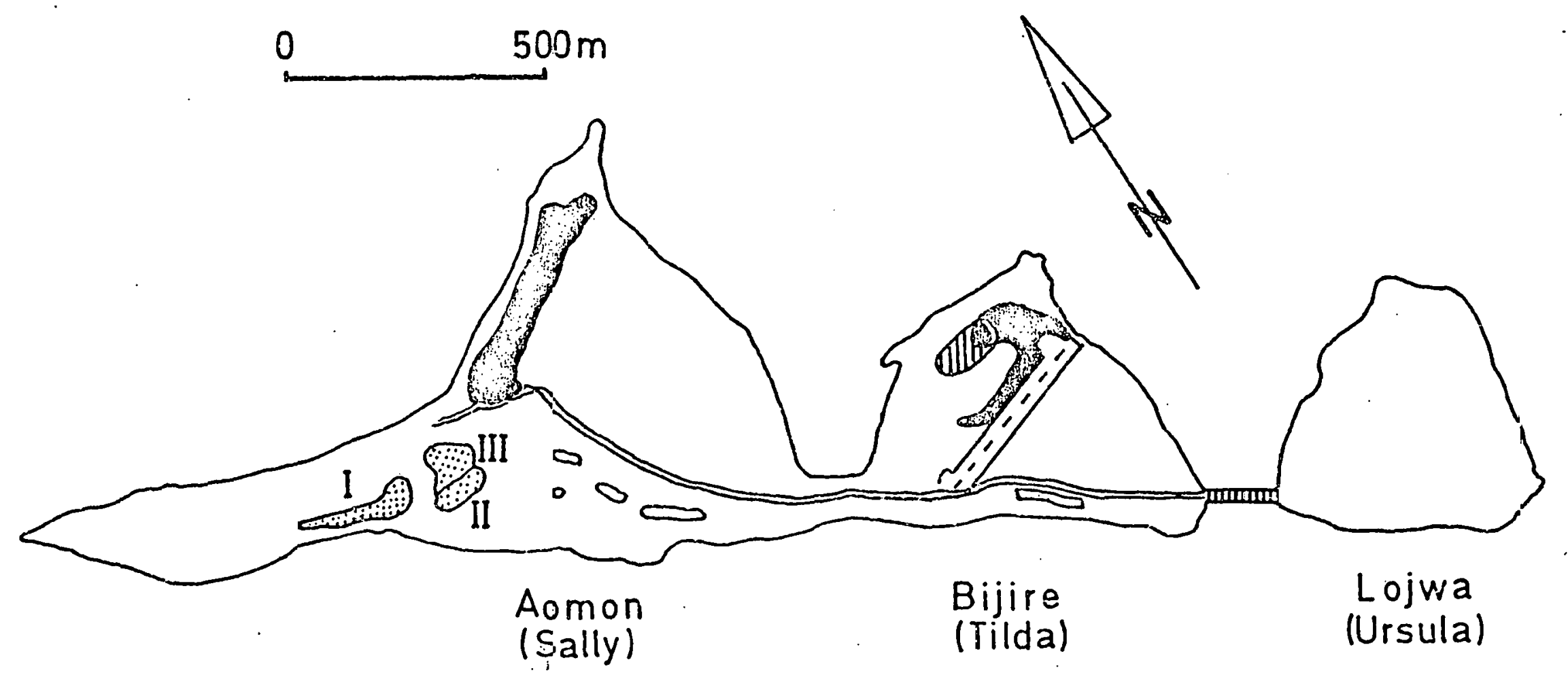

E Areas of rat trapping (R. exulans)

Wedge-tailed Shearwater (Puífinus pacificus) colony

Sooty Tern (Sterna fuscata) coiony

I as of Nov. 14; II Nov. 15; III Nov. 21.

$\infty$ Freshwater pools 


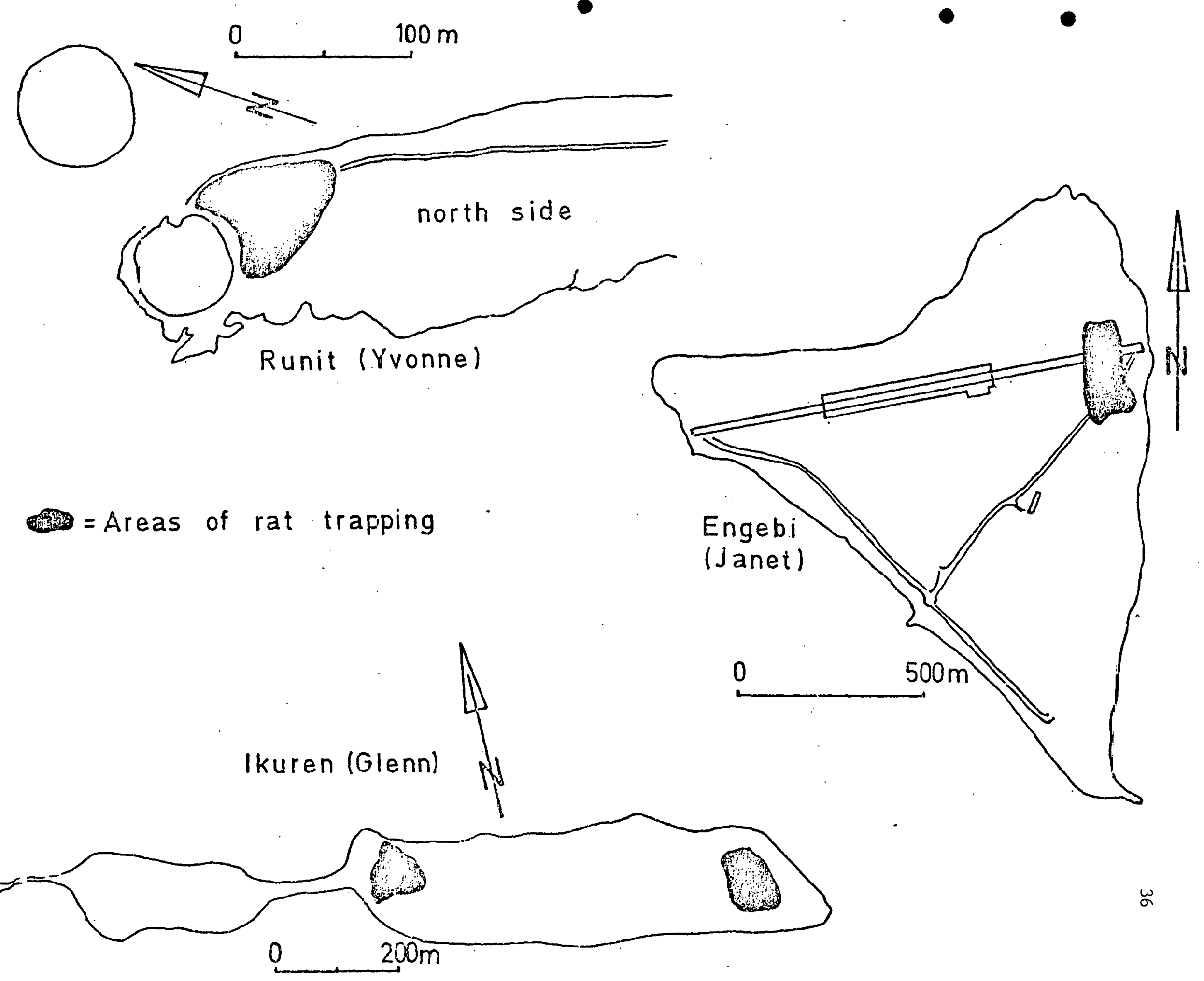


Table I. Summary of bird species obssrved at: Ene!!etak Atoll

Spacies. Islets Enjebi Aomon Bijire Lojwa Runit Ananij ileģren Ene!:etalk Ikuren

\section{Puffinus pacificus}

Fhaethon rubricauda

Phesthon lepturus.

Gula sula

Sula lcuconaster

Freg:ta mincr

St:irna sumatrana

Gtorna ruscite

Sterna bergii

Anous stallidus

inous tenuirostris

Gygis alija

Egretta_sacre

Anas $5 n$.

Pluvialis dominica

Cheradrius mongolus

Humenius phaeopus

Uumenius Jahiliensis

Limos? 1.rpponica

Tringa glareola.

Heteroscelus incanum

Arcnari: inierores

Calidris acuminata 100

2

6

100

10000

200

ธิCD

16

3

100

1

1

10

3

80

\section{?}

3

540

5

1

15

6

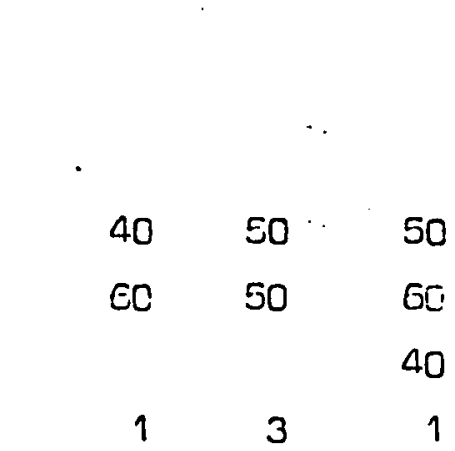

12

15.

4
2

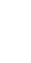

3

5

30

10
Total

100

2

5

1

7

6

13

$1010 \mathrm{C}$

19

$650^{+}$

$1480^{+}$

145

13

3

$\begin{array}{rr}60 & 50 \\ 1 & \\ 1 & 1 \\ 1 & 5 \\ 1 & \end{array}$

$8 \quad 15$

$40 \quad 50$

270 
TABLE 2. Summary of external reproductive condition of male rats caught at Enwetak Atol1, 7-23 November, 1977.

\begin{tabular}{|c|c|c|c|c|c|c|c|c|}
\hline Islet & Sfecies & $\begin{array}{l}\text { Old } \\
\text { Adult }\end{array}$ & Adult & $\begin{array}{l}\text { Young } \\
\text { Adult }\end{array}$ & Juvenile & TOTAL & $\begin{array}{l}\text { Testis } \\
\text { Scrotal }\end{array}$ & $\begin{array}{l}\text { Body } \\
\text { Scars }\end{array}$ \\
\hline Bijire & R. exulans & 2 & 6 & 4 & 0 & 12 & 12 & 6 \\
\hline Aomon & R. exulans & 1 & 2 & 2 & 2 & 7 & 5 & 2 \\
\hline I kuren & R. exulans & 1 & 13 & 0 & 0 & 14 & 14 & 5 \\
\hline TOTAL & & 4 & 21 & 6 & 2 & 33 & 31 & 13 \\
\hline Runit & R. rattus & 0 & 11 & 0 & 1 & 12 & 11 & 1 \\
\hline Enjebi & R. rattus & 4 & 7 & 4 & 0 & 15 & 15 & 1 \\
\hline Ananij & R. rattus & 5 & 12 & 2 & 0 & 19 & 19 & 3 \\
\hline TOTAL & & 9 & 30 & 6. & 1 & 46 & 45 & 5 \\
\hline
\end{tabular}


TABLE 3. Summary of pelage characteristics of male and female rats caught at Enewetak Atoll, 7-23 November 1977.

Pelage of Male and Female Grouped

\begin{tabular}{rllll} 
Agouti Agouti Gray/ & Black & Black/ Agoutitred Agouti+Black \\
Islet White & /Gray Slate gray Slateg Black Slategray Slate gray \\
\hline
\end{tabular}

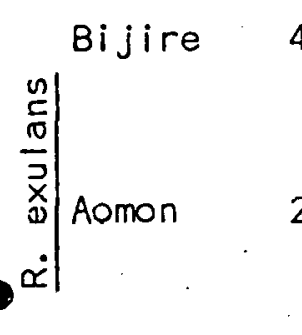

$\begin{array}{llll}0 & 0 & 0\end{array}$

0

Ikuren $21 \quad 0$

0

0

0

0

0

TOTAL

82

0

0

0

0

0

0

Runit

$0 \quad 0$

1

19

0

0

0

0

0

\begin{tabular}{c|c}
9 \\
\pm \\
+ \\
$\mathfrak{0}$ \\
$\dot{x}$ \\
$\mid$
\end{tabular} \mid Enjebi

$43 \quad 2$

Ananij

7

3

15

.1

8

TOTAL. 50

5

2

34

2

9 
TABLE 4. Summary of external reproductive condition of female rats caught at Enewetak Atoll, 7-23 November, 1977.

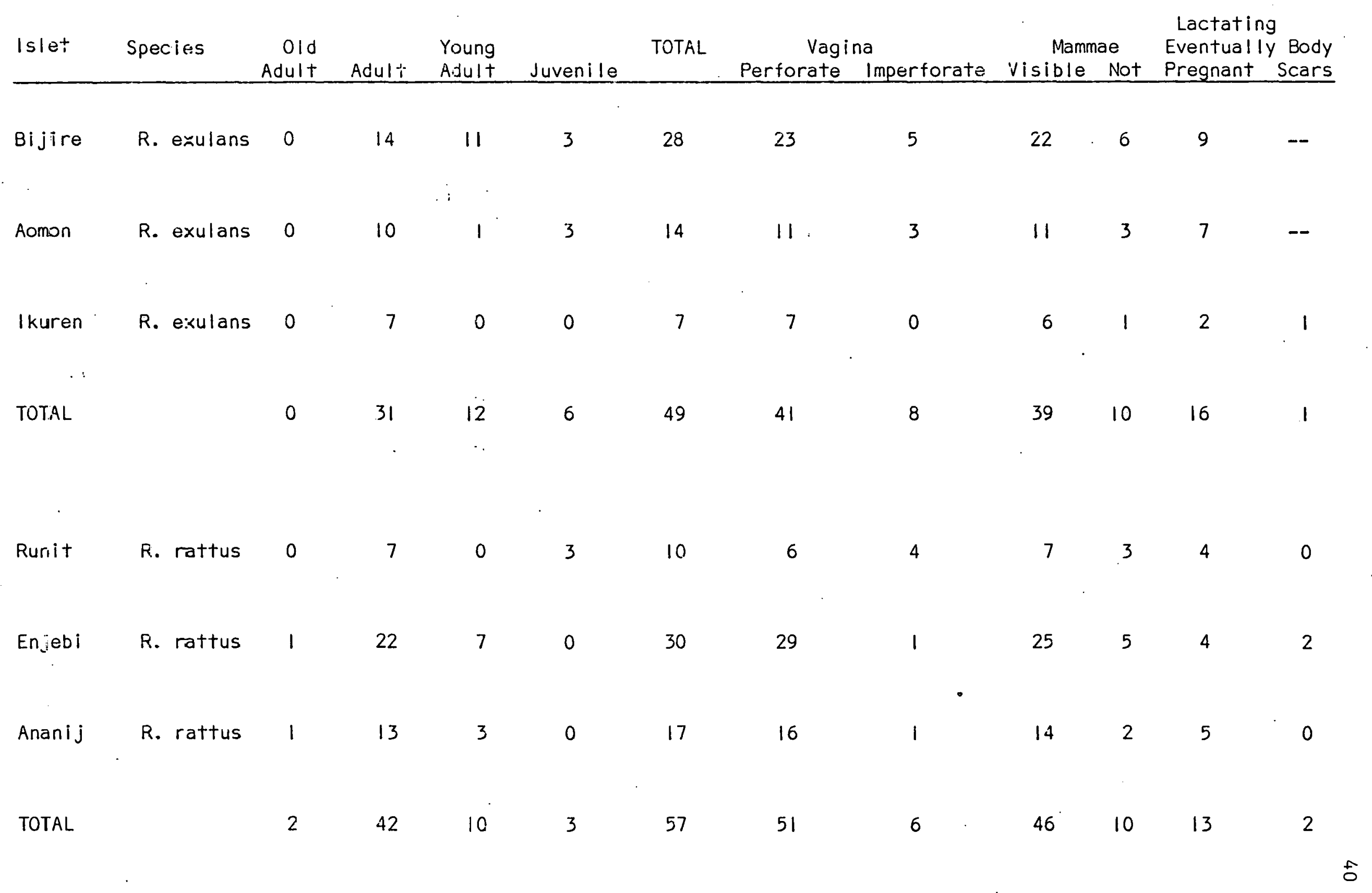


Calidris acuminata: Although this species is called a common migrant to the Marshal1. Islands (Baker, 1951; Amerson, 1969), it is not regularly seen at the Enewetak Atoll (Carpenter et al., 1968). This might be due to lack of freshwater on the islets. On Aomon where several freshwater pools had been found on November 9, 12 specimens were seen. On a subsequent visit to the islet, the number of birds present had not changed. This species was in company with Tringa glareola, Pluvialis dominica and Arenaria interpres. Tringa glareola in company with this species already has been described by Baker (1951).

\section{RAT TRAPPING AND DOSIMETER RECOVERY ATTEMPTS OF MARCH-APRIL 1978}

Dosimeters implanted in more than 160 rants last fall were sought. About a $25 \%$ recovery rate (through trapping) was experienced. Data derived from these units have not yet been received. Some rats were processed through a whole body counter, and gamma emission data (especially $137 \mathrm{Cs}$ ) have been obtalned. These preliminary data indicate that rats can be used as effective environmental monitors.

Data derived from routine trapping and autopsy of rats are summarized in the attached tables. Nearly 1,000 rats were examined. Normally this time of year is characterized by little or no reproduction. Only in grossly disturbed habitats with abundant food supplies (e.g., Lojwa) was this not true. 


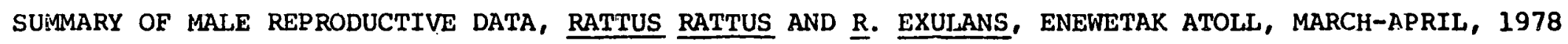

\begin{tabular}{|c|c|c|c|c|c|c|c|}
\hline Islet & Species & Total & $\begin{array}{l}\text { No. } \\
X Y\end{array}$ & $\begin{array}{l}\text { No. } \\
\text { Non-scrotal }\end{array}$ & $\begin{array}{l}\text { No. } \\
\text { Epididymis } \\
\text { w/o tubules }\end{array}$ & $\begin{array}{l}\text { otal } \\
\text { Epididymis } \\
\text { w/ tubules }\end{array}$ & $\begin{array}{c}\text { Epididymis } \\
\mathrm{XY}\end{array}$ \\
\hline Enewetak & (R. rattus) & 14 & 0 & 1 & 2 & 11 & 0 \\
\hline Medren & & 54 & 0 & $4^{\star}$ & 4 & 43 & 3 \\
\hline Bruce & & 27 & 0 & 6 & 5 & 11 & 5 \\
\hline Engebi & & 68 & 1 & $8 *$ & 3 & 56 & 0 \\
\hline Runit & & 40 & 4 & 2 & 1 & 33 & 0 \\
\hline Kate & & 9 & 0 & 3 & 0 & 6 & 0 \\
\hline Igurin & (‥ exulans) & 51 & 1 & 13 & 8 & 23 & 6 \\
\hline Aoman. & & 31 & 0 & 0 & 1 & 29 & 1 \\
\hline Bijiri & & 39 & 0 & 1 & 3 & 33 & 2 \\
\hline Lowja & & 44 & 0 & 8 & 4 & 12 & 20 \\
\hline Japtan & & 49. & 0 & 11 & 5 & 8 & 25 \\
\hline Keith & & 33 & 0 & 0 & 6 & 12 & 15 \\
\hline Pearl & & 22 & 0 & 2 & 2 & 2 & $16^{\star *}$ \\
\hline TOTALS & & 481 & 6 & 59 & 44 & 279 & 93 \\
\hline
\end{tabular}

*includes one that had epididymis with tubules

**plus 11 without data 
SUMMP.RY OF FEMALE FEPRODUCTIVE DATA, RATTUS RATTUS AND R. EXULANS, ENEWETAK ATOLL, MARCH-APRIL, 1978

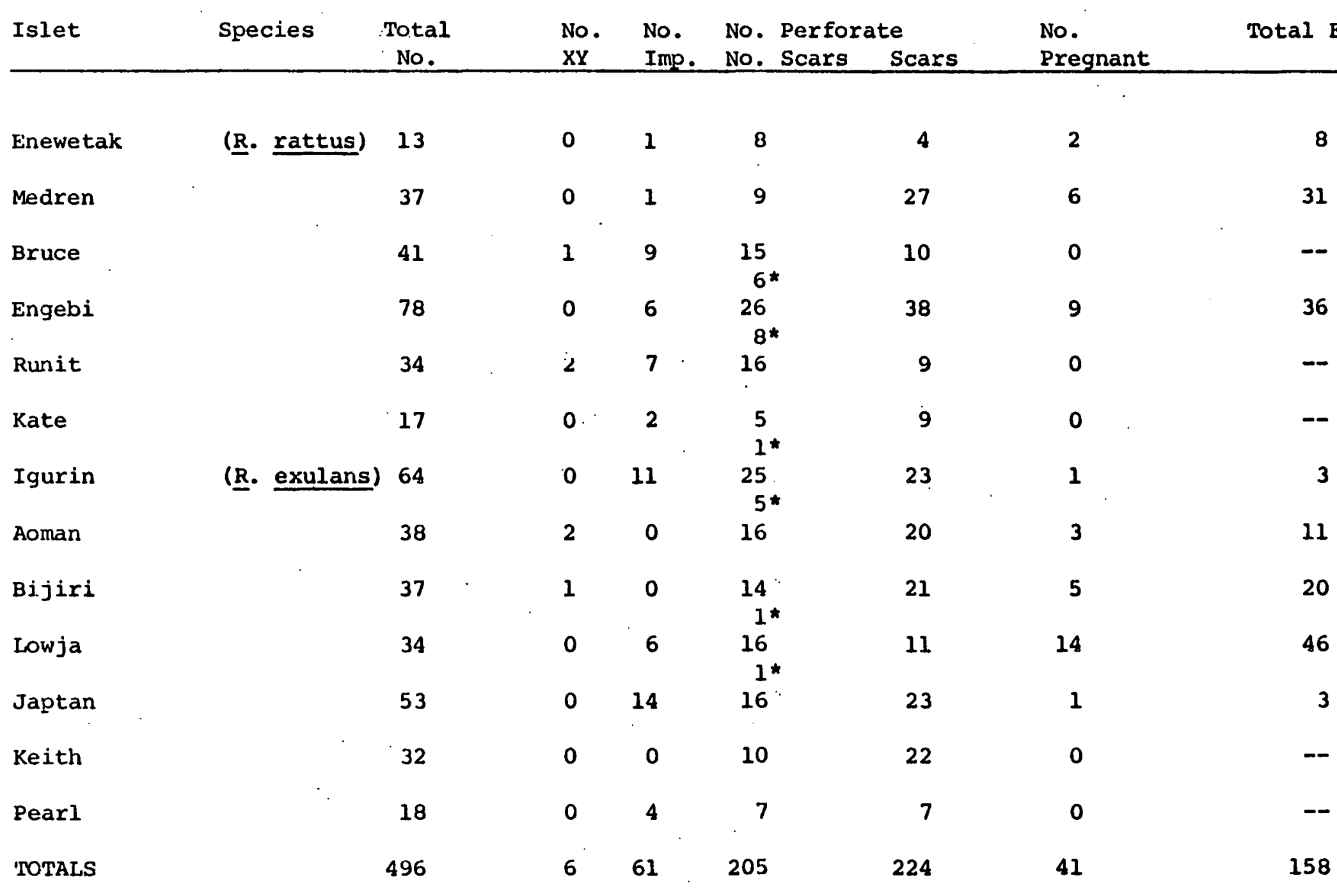




\begin{tabular}{|c|c|c|c|c|c|}
\hline Islet & Species & $\begin{array}{l}\text { No. Stomachs } \\
\text { Examined }\end{array}$ & $\begin{array}{c}\text { No. }>75 \% \\
\text { Plant } \\
\text { Material }\end{array}$ & $\begin{array}{r}\text { No. }>20 \% \\
\text { Animal } \\
\text { Material }\end{array}$ & $\begin{array}{c}\text { No. trace } \\
\text { Animal } \\
\text { Materials }\end{array}$ \\
\hline Medren & (R. rattus) & 21 & 21 & 0 & 2 \\
\hline Kate & & 23 & 23 & 0 & 0 \\
\hline Enewetak & . & 19 & 18 & 2 & 2 \\
\hline Engebi & & 51 & 51 & 0 & 1 \\
\hline Keith & & 12 & 7 & 5 & 0 \\
\hline Igurin & & 14 & 14 & 0 & 1 \\
\hline
\end{tabular}

SUMMARY OF STOMACH NEMATODE (PROTOSPIURA SP.) ANALYSES, ENEWETAK ATOLL, MARCH-APRIL 1978

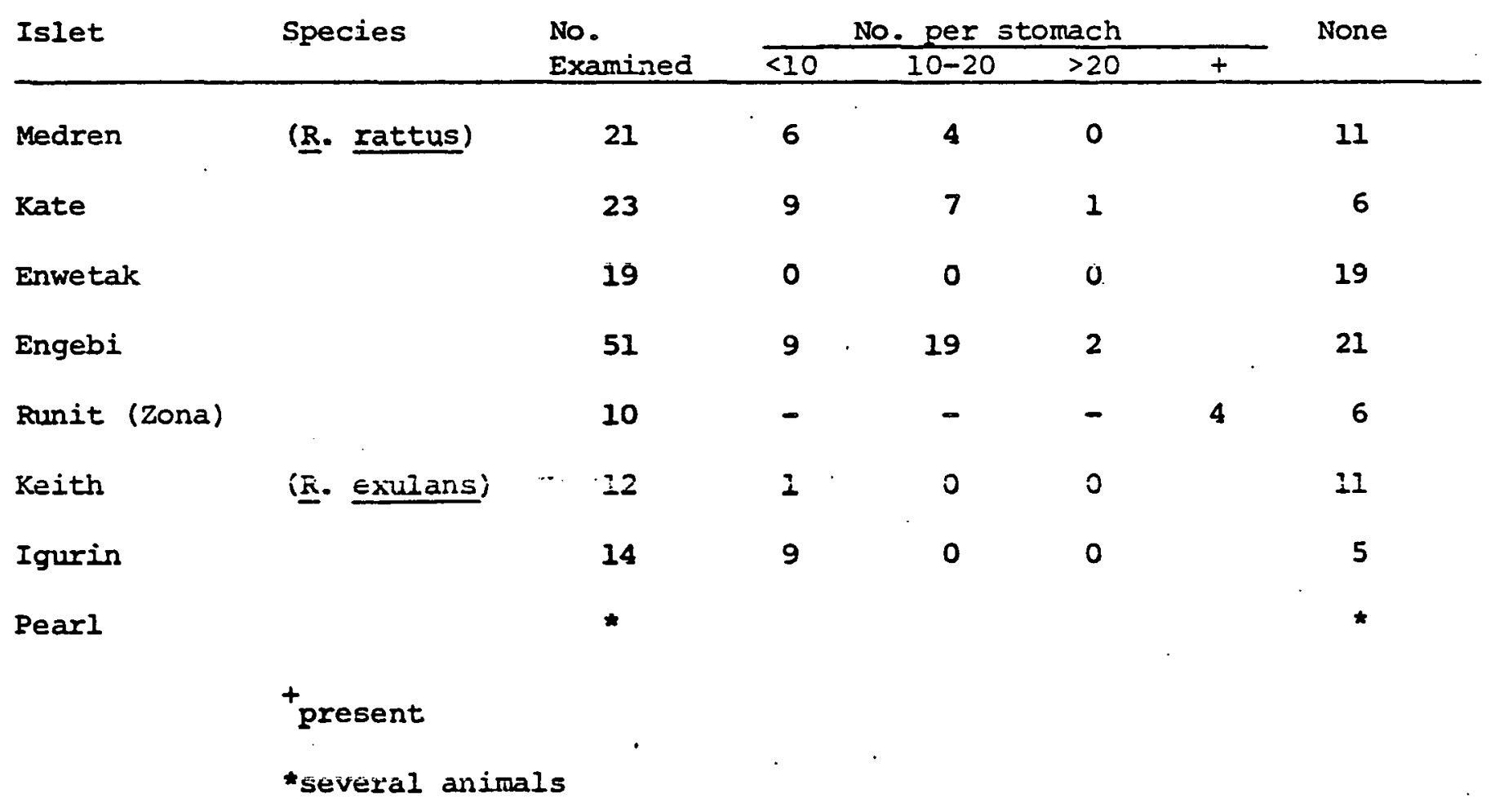


SUMMARY OE Rattus rattus pelage colors, Enewetak Atoll, March-April, 1979.

DORSAL VENTRAL COLORATION

Islet

Enewetak

Runit

Kate

Bruce

Medren

Engebi
No. Examined

27

75

26

68

91

146
Agouti/White

22

10

26

26

88

129
Agouti/Grey

1

9

0

5

0

14
Black/Black

$X Y$

$\begin{array}{cc}0 & 4 \\ 56 & 0 \\ 0 & 0 \\ 37 & 0 \\ 3 & 0 \\ 3 & 0\end{array}$


SUMMARY OF BODY CAVITY FAT TISSUE IN ENEWETAK RATS, MARCH-APRIL 1978

Fat Condition Class

\begin{tabular}{|c|c|c|c|c|c|c|c|}
\hline Islet & & Total & 1 & 2 & 3 & & $X Y$ \\
\hline Enewetak & $M$ & 14 & 12 & 2 & 0 & & 0 \\
\hline $\mathrm{N}=27$ & $\mathbf{F}$ & 13 & 9 & 4 & 0 & & 0 \\
\hline Medren & $\mathbf{M}$ & 54 & 9 & 26 & 15 & & 4 \\
\hline $\mathrm{N}=91$ & $F$ & 37 & 9 & 16 & 12 & & 0 \\
\hline Bruce & $\mathbf{M}$ & 27 & 14 & 8 & 0 & & 5 \\
\hline$N=68$ & $\mathbf{F}$ & 41 & 23 & 8 & 3 & & 7 \\
\hline Engebi & $M$ & 68 & 54 & 11 & 1 & & 2 \\
\hline$N=146$ & $\mathbf{F}$ & 78 & 47 & 21 & 2 & & 8 \\
\hline Runit & $\mathbf{M}$ & 40 & 28 & 7 & $1 *$ & & 4 \\
\hline $\mathrm{N}=75$ & $\mathbf{F}$ & 34 & 22 & $\begin{array}{l}8 \\
1 * *\end{array}$ & 1 & & 3 \\
\hline Kate & $\mathbf{M}$ & 9 & 3 & 6 & 0 & & 0 \\
\hline$N=26$ & $\mathbf{F}$ & 17 & 9 & 8 & 0 & & 0 \\
\hline Igurin & $M$ & 51 & 20 & 16 & 7 & . & 8 \\
\hline $\mathrm{N}=115$ & $\mathbf{F}$ & 64 & 22 & 21 & 10 & & 11 \\
\hline Aoman & $\mathbf{M}$ & 31 & 14 & 11 & 4 & & 2 \\
\hline $\mathrm{N}=69$ & $F$ & 38 & 6 & 19 & 9 & & 4 \\
\hline Bijiri & $\mathbf{M}$ & 39 & 4 & 17 & 18 & ' & 0 \\
\hline $\mathrm{N}=76$ & $\mathbf{F}$ & 37 & 1 & 13 & 21 & & 2 \\
\hline Low̄ja & $M$ & 44 & 2 & 26 & 14 & & $2 r$ \\
\hline $\mathrm{N}=79$ & $\mathbf{F}$ & 34 & $\begin{array}{l}5 \\
1 * *\end{array}$ & 17 & 12 & & 0 \\
\hline Japtan & $\mathbf{M}$ & 49 & 0 & 0 & 1 & & 48 \\
\hline$N=102$ & $\mathbf{F}$ & 53 & 1 & 26 & 26 & & 0 \\
\hline Keith & $M$ & 33 & 1 & 6 & 9 & & 17 \\
\hline $\mathrm{N}=65$ & $\mathbf{F}$ & 32 & 0 & 11 & 21 & & 0 \\
\hline Pearl & $\mathbf{M}$ & 22 & 4 & 4 & 0 & & 14 \\
\hline$N=51$ & $F$ & 18 & 6 & 5 & 1 & & $\begin{array}{c}6 \\
11 \star \star \star\end{array}$ \\
\hline $\begin{array}{l}\text { TOTALS } \\
\mathrm{N}=990\end{array}$ & & $977(+13 \underset{* \star}{* x})$ & 326 & 318 & 188 & & $147\left(+11^{+++}\right)$ \\
\hline
\end{tabular}


Project: Endolithic biology of atolls - geologic aspects

Investigators: Jere H. Lipps

Department of Geology

University of California

Davis, California 95616

Thomas E. Ronan

Department of Earth and Planetary Sciences

University of California

Los Angeles, California 90024

Objective: To determine the reef carbonate "budget" in order to interpret both modern and fossil reef history and ecology.

We concentrated on the contribution of foraminifera to the carbonate budget, and on the contribution of bioturbation and organic constituents in the sediments of various habitats. The study of bioturbation and the organic constituents of sediments was pursued by the collection of samples. Both sediment and reef rock were returned to UCLA for analysis and study by Ronan. None of these studies were completed because of the death of $\mathrm{Dr}$. Ronan shortly after our return to the mainland.

Foraminifera are an important contributor to the carbonate of reefs. First, many of them contain algal symbionts which aid in the production of $\mathrm{CaCO}_{3}$ in their tests, most of which are very large. Secondly, in some habitats on the reef foraminifera reproduce and die or are killed through predation very rapidly, thus producing numerous tests.

Foraminifera which contain symbionts were observed in the field to determine their distribution with depth and microhabitats. Our field observations suggest that Amphisorus, a large discoidal form, lives in shallow parts of the reef and particularly on Halimeda. We believe that Amphisoms is able to survive here because fish cropping of Halimeda is limited. Thus the foraminiferan is protected from cropping and probable death because it seeks the higher parts of the Halimeda. Heterostegina, another large foraminiferan which is known to possess diatom symbionts, lives at all depths down to at least $35 \mathrm{~m}$ (lower diving limit), but its abundance and habitat vary. In shallow waters it can be found clinging to algae, in cracks and in bioeroded holes. Again fish seem to be the primary destroyer of the foraminiferan in unprotected areas. At deeper depths (approximately 10 to $20 \pm \mathrm{m}$ ), Heterostegina lives under the edges of stable reef rubble, where there seems to be some available light for its symbionts but where it is again protected from predation or cropping by fish and holothuroids. Homotrema, a large, erect and attached form, has a test that in later life is cxtended by long projections. These projections of the test seem to serve as a means of deploying pseudopodia into the water column for feeding. In tiny cavities, several specimens have been observed with 
pseudopodial nets intertwined and completely blocking the cavity, thus filtering any currents which pass through. The genus usually lives most abundantly in cavities created by endolithic borers, in cracks, or in spaces under rubble, again at depths between 10 and $30 \mathrm{~m}$. It occurs also in shallower water, but in the most protected places. In these situations its branches are shorter, stockier, and more robust than in deeper water. Deeper water forms have long delicate branches.

One genus, Tretomphalus (or Rosalina depending on systematic usage) has an unusual reproductive (?) mode that disperses carbonate from the reef and reef sediment to deeper waters. Species of this genus form float chambers and become temporarily planktonic; this has been associated with reproduction at temperatures warmer than about $18^{\circ}$. Unpublished information from the Great Barrier Reef suggests that some species of this genus undergo diurnal migrations from the sediment and reef structure into the water column and perhaps return. Several night and day plankton tows were made at Enewetak to determine whether or not this also occurred there: No specimens were caught, although they have been reported earlier in the year by other investigators.

Heterostegina, Amphisorus and Homotrema were selected for culture work at UC Davis. Numerous specimens were selected from samples and transported successfully to UC Davis, where cultures have been established. Heterostegina has adapted well to culture techniques, but Homotrema is not doing well. We presume that Homotrema requires some particulate food to filter which we have not discovered yet. Heterostegina is now adding chambers, although none have reproduced. The tests of some of these have been prepared by ion-beam thinning for transmission electron microscopy of the test ultrastructure.

Plans for future work include study of the morphological manifestation of the symbiont--foraminiferan relationship so that such symbiosis in fossil foraminifera can be detected; of the test ultrastructure of various species collected at Enewetak; of the calcification process as revealed by TEM of newly calcifying tests; and of the habitat data so that the relation of symbiont-bearing foraminifera to reef location can be determined.

This work will also be coordinated with work to be done in a December, 1978, Enewetak visit by $\mathrm{Dr}$. John Warme of Rice Universicy (see annual report FY79). 
Project:

Investigators:

Objectives:
Social behavior and aggression in the gray reef shark, Carcharhinus amblyrhynchos: studies using ultrasonic telemetry and submersible observation

Donald R. Nelson

James N. McKibben

Robert R. Johnson

Gregory G. Pittenger

Department of Biology

California State University

Long Beach, California 90840

Ralph Nelson

Rod Allin

Marlin Perkins

Don Meier Productions

520 North Michigan Avenue

Chicago, Illinois 60611

1. To test the feasibility of a combined "telemetry/ submersible" approach to the observational and experimental study of dangerous sharks at Enewetak.

2. To investigate social behavior, especially aggression towards divers and submersibles, as related to patterns of grouping and spacing.

3. To produce a $16 \mathrm{~mm}$ film documentary on the above research.

Previous experiences at Enewetak indicated that certain types of needed behavioral studies on gray reef sharks would be too risky for unprotected divers. For this reason, a specially designed, bite-proof, "Shark-Observation Submersible" was constructed to provide a safe observation platform, diver-to-surface communications, and the increased mobility needed to intercept telemetered sharks. The sub was designed for both (1) observation alone, and (2) experimentation, in which the sub itself is used as a model to elicit responses from sharks.

The prototype, one-man, wet craft is $8^{\prime}$ long and $2^{\prime}$ in maximum diameter. The streamlined fiberglass hull has an acrylic-dome entry port at the forward end, which also provides good visibility for the prone diver within. The scuba air supply and battery pack are mounted inside, and the sub is buoyed neutral by internal syntactic foam. The three electric motors, two forward "pectoral" fins, and the aft tail fin are all independently controllable. The sub was carried athwartship aboard the MPML 21' Whaler on a special aluminum-rail platform which was used for launch and recovery. 
Using the sub, two attacks by gray sharks were experimentally elicited by approaching individuals in agonistic display and partially cornering them. These attacks were sudden, high-speed strikes, prefaced by display of maximum intensity. Initial display was released by approach and pursuit by the sub, with the shark slowing forward motion and intensifying display as the sub neared. Each attack occurred when the sub had closed to about $2 \mathrm{~m}$, at which point the shark was somewhat (not highly) cornered, a situation which it made no attempt to avoid. Just prior to attack, each shark rolled on its side, nearly 90 degrees, possibly to help see the sub approaching from above.

Attack no. 1 resulted in deep tooth scratches on the hull just behind and above the left motor. In attack no. 2, the shark bit the right motor, breaking the lexan propellor. In each case, agonistic display was maintained after the attack as the shark swam off. Both attacks occurred on the same dive in $S$. Channel about $1-2 \mathrm{~km} E$. of Glenn in about 12-15 m of water. One attack (possibly both) was by a female of about $1.5 \mathrm{~m}$ total length. While several bait-attracted grays were in view, one displaying individual (possibly the attacker) was present prior to baiting.

Both complete attack sequences were filmed (one quite clearly) by cameraman Ralph Nelson, and the $16 \mathrm{~mm}$ frames are being used for more detailed behavioral analyses. These attacks significantly emphasize the danger of moving close to gray sharks in display. They confirm the previous observations of W. Starck (EMBL Ann. Rep., 1971-72) who elicited similar attacks at Enewetak using a larger, two-man submarine. They are also important in establishing the feasibility of using small submersibles for the direct experimental study of shark attack.

To continue the study of home range and diel movements started in 1976, intermittent telemetry trackings were conducted on seven sharks, three by body-cavity implantation (captured sharks), four by selfingestion-in-bait (non-captured sharks). Movements were tracked with a newly designed ultrasonic transponding system which provided exact readout of distance-to-shark, thereby facilitating the interception and identification of telemetered individuals. The transmitters $(3 \mathrm{~km}$ detection range) continually pulse at one/second, but respond to an interrogate pulse by emitting an additional reply pulse from which distance is calculated and digitally displayed. With a prototype diverheld interrogate unit, distances were readable to about $200 \mathrm{~m}$.

Among the 1977 trackings were (1) a lone female in S. Channel near Glenn which exhibited approach and subsequent display towards divers, (2) another females from the $S$. Channel drop-off area wh1ch was contacted in the same area as long as 21 days after implantation, and (3) an individual tagged at the "dome" pinnacle $(9.8 \mathrm{~km} \mathrm{~W}$ of concrete ship) which was tracked day and night over a three-day period. This individual had a predictable diel area shift, and also showed the largest home range of any gray shark thus far tracked at Enewetak. It spend the daylight hours at or near the dome pinnacle, while at night it ranged widely to the south as far as S. Channel (near Enewetak to near Glenn). This shark had a home range (maximum polygon plot) of $10.5 \mathrm{~km}$ long, $7.3 \mathrm{~km}$ wide, with an area of about $53 \mathrm{~km}^{2}$. 
Based on this and previous visits, the observed daytime grouping habits of non-baited gray reef sharks have been of the following three intergrading types: (1) loose aggregations - usually near ocean-reef drop offs, generally characterized by attraction to divers, moderate tendency for agonistic display, non-parallel swimming, and an apparently non-social exploratory motivation, e.g., as if seeking a feeding opportunity. (2) Organized packs (polarized schools) - seen close to bottom over more level coral and sand, characterized by non-attraction to divers, lowest tendency for agonistic display, much parallel swimming and following, and an apparently social motivation, possibly refuging. (3) "Lone" individuals (sometimes two or three) - over shallower reef areas or isolated lagoon pinnacles, characterized by attraction to divers, high tendency for agonistic display, and apparently some social motivation, possibly territoriality, although evidence for this is conflicting. Most cases of display and attack on divers at Enewetak have involved individuals of the "lone" type. 
Project:

Investigators:

Objectives:
Updating, organization and care of MPML reference collection

John E. Randall

Arnold Y. Suzumoto

Ann Fielding

Bernice P. Bishop Museum

P. 0. Box 6037

Honolulu, Hawaii 96818

Richard A. Boolootian

Science Software Systems, Inc.

11899 West Picó Blvd.

West Los Angeles, California 90064

1. Update, organize and care for the reference collections.

2. Conduct or establish experiments yielding further necessary data on the growth rates of Thidacna gigas (giant clam) and Triaenodon obesus (whitetip reef shark).

Eleven previously unrepresented species were added to the MPML fish collection. Eighteen name changes were made covering 11 families, bringing the fish collection up to date in terms of current species names.

The invertebrate collection was inventoried and updated, and all jars (fishes as well as inverts) were refilled as necessary, with preservative.

A number of giant clams, part of an ongoing study of growth rates, were measured. 
Project:

Inves tigators :

Objectives:
Behavioral ecology of coral reef fishes especially butterfly fishes

Ernst S. Reese

Lisa M. Boucher

Philip Motta

Department of Zoology

University of Hawaii

Honolulu, Hawaii 96822

1. To continue the study of the home ranging and territorial obligate coral feeding species.

2. To extend the study to include more individuals.

3. To begin the study of omnivorous species, gathering data on their diet and movements and social interactions on the reef.

4. To elucidate the anatomical adaptations of the feeding apparatus of this family of fishes.

5. To study resource partitioning on the reef, evolutionary pressures guiding their anatomical and behavioral adaptations, and how these adaptations have resulted in coevolution of the coral reef and the butterflyfishes.

The same individual $C$. trifasciatus were present in the same home range areas of Medren Pinnacle as were present in previous years. The same was true of the $C$. trifascialis. From observations on the social interactions of these individuals, it is clear that they know one another and are aware of the boundaries of the home ranges and territories.

From variation in the marking patterns, it was possible to learn three pairs of $C$. ephippium. These pairs ranged over the entire pinnacle and are therefore correctly described as broadly home ranging. They swim in male and female pairs. They feed on the fine turf of algae and detritus which covers the coral rubble on the bottom.

A similar study was made of $C$. Ulietensis (=C. falcula). This species also swims in paris over a large area of the reef. It feeds on a wide variety of benthic invertebrates, and is therefore correctly described as being both omnivorous and carnivorous. Its sociobiology resembles that of C. ephippium.

It was possible to recognize only 5 of the 11 C. unimaculatus individuals studied on Medren Pinnacle the year before, but these continued to inhabit virtually the same core home range as the year 
before, and accompanied the same companion fish, indicating that the group associations studied in the previous year are very stable. Observations at "Reference" and "Study" reefs located between Sand Island and Medren indicate that $C$. unimaculatus exist in a more loosely structured system of social organization there than at Medren Pinnacle. At the Reference and Study sites they were seen to wander as pairs or small groups with no obvious home range. In Kaneohe Bay, Oahu, Hawaii, C. unimaculatus can be found in large schools of up to 50 individuals which feed on a wide variety of organisms.

Based on this information it can be hypothesized that C. unimaculatus' social structure represents a case of behavioral scaling, a phenomenon in which aggressiveness and territoriality are observed to increase with increasing population density. The pairs and small groups of $C$. unimaculatus observed at the Reference and Study sites may indicate the "low" end of the behavioral scale, with a very small population density, and very little sociality or aggression. The population at Medren may be the "middle" of the scale. An increased population density may be responsible for the aggression and territoriallty observed there. Aggression isseen in the Kaneohe Bay population, but more work will have to be done in order to quantify this observation and relate it to the large population size there.

Data was also collected on the mechanics of feeding, i.e., the angle assumed by the fish during feeding, the location on the coral fed upon, and the shape and species of coral fed upon. Species studied for feeding mechanics include Chaetodon omatissimus, C. unimaculatus, $C$. trifasciatus, $C$. trifascialis and $C$. auriga. An angelfish Centropyge flavissimus, was also collected for studies on its teeth. The list of feeding guilds being studied at Hawaii and Enewetak thus includes: coral polyp pickers, planktivores, omnivores and herbivores.

To date there appears to be little difference in the feeding angle of the fish at both Hawaii and Enewetak except C. trifascialis, which has an angle lower than the others, a fact that may be correlated with its feeding location on the edges of the table-like coral, Acropora hyacinthus. It appears that surge and/or coral species and/or coral shape may affect the feeding angles and thus how the fish utilize their food source.

Observations on the actual species of coral being fed upon were collected by recording feeding events of the various fish. This data will yield the food preferences for each species, as well as where on the coral head the fish feed more frequently. Both this and the previous data will be utilized to draw conclusions about the feeding adaptations of the butterflyfish, the feeding behavior (among the various guilds), the food preference, and the effects the feeding may be having on coral growth, distribution and shape. 
It appears that the various species have significantly different choices in their coral preference and that species that were previously classified as obligatory coral polyp feeders are in fact very opportunistic in their choice of food items, as in fact are most of the species.

An extremely valuable set of observations was made when the study area was subjected to a few days of dense planktonic food. All the species which have been studied switched their feeding behavior to the plankton feeding mode to take advantage of the rich food supply.

Specimens removed from Enewetak were also prepared for scanning electron microscopy on the jaw teeth to compare dentitions among the various guilds. 
Project:

Investigators: Anthony R. Russo

Geoffrey Akita

August Riccio, Jr.

Science Department

Leeward Community College

Pearl City, Hawaii 96782

To ascertain the degree of bioerosion by two species of echinoids on a lagoon side subtidal coral knoll and on a seaward intertidal reef platform.

Two environments were chosen at Enewetak Atoll. One, a coral knoll was located south of Medren Island in the Enewetak lagoon and the other, a reef platform, 100-200 yards north of the MPML facilities. Permanent $100 \mathrm{~m}$ transects were placed at each site held fast by concrete nails and marked at every five (5) meters. On the reef platform a transect was permanently placed approximately 50 meters and 150 meters from shore. Burrows of the sea urchins Echinometra mathaei and Echinostrephus aciculatus were marked with red tags and measured (diameter, length, width, depth, etc.). Burrows will be reexamined in six-eight months for enlargement and gross estimates of volume rate increase will be determined. Knowing the density of limestone $\left(2 \mathrm{y} / \mathrm{cc}\right.$ ) an estimate of $\mathrm{CaCO}_{3}$ eroded by the urchins can be determined. Along with burrow dimensions, test diameters and density $\left(\# / \mathrm{m}^{2}\right)$ were measured at each transect location.

Gut content (fecal pellets) were analyzed for both species. A turnover of gut contents was determined for both species and from this an estimate of weight of $\mathrm{CaCO}_{3}$ removed per unit time was obtained. See Table 1 for all of the details. Erosion rates of each species were determined as a function of size class. Briefly, results showed a significant difference in mean size of both species between the lagoon and seaward reef platform habitats. Densities were also significantly different not only between habitats but also between the two transects placed on the reef platform (one close to seaward edge and the other close to shore). Preliminary results show that erosion rates of both urchins are consistent, at least within the same order of magnitude, with other workers (Stearn et al. [1977], McLean [1967] and Ogden 1977). Follow up studies on burrow enlargements will be used to measure the effectiveness of this method in approximating erosion rates obtained by the more rigorous gut analysis. method. Erosion rates of $E$. aciculatus, whose burrows are strikingly cylindrical, may prove to be measurable by this method whereas the erosion rates of $E$. mathaei whose burrows are very irregular may prove to be impossible to measure using burrow enlargement. 
Table 1. Erosion rate statistics

\begin{tabular}{|c|c|c|c|c|c|c|c|}
\hline Environment & Species & $\begin{array}{c}\text { Density } \\
\# / \mathrm{m}^{2}\end{array}$ & $\begin{array}{l}\text { \% Fre- } \\
\text { quency* }\end{array}$ & $\begin{array}{l}\text { Mean } \\
\text { Size } \\
(\mathrm{cm}) \\
\end{array}$ & \begin{tabular}{l}
\multicolumn{1}{c}{$\mathrm{N}$} \\
Sam- \\
ple \\
Size
\end{tabular} & $\begin{array}{l}\text { Mean } \\
\text { Erosion } \\
\text { Rate } \\
\mathrm{g} / \mathrm{d} \\
\end{array}$ & $\begin{array}{l}\text { Total } \\
\mathrm{CaCO}_{3} \\
\text { Erosion } \\
\mathrm{g} / \mathrm{m}^{2} / \mathrm{y}\end{array}$ \\
\hline Coral knolls & $\begin{array}{l}\text { E. mathaei } \\
\text { E. aciculatus }\end{array}$ & $\begin{array}{l}0.16 \\
0.50\end{array}$ & $\begin{array}{l}14.5 \\
24.0\end{array}$ & $\begin{array}{l}2.20 \\
2.40\end{array}$ & $\begin{array}{r}40 \\
120\end{array}$ & $\begin{array}{l}.1375 \\
.3990\end{array}$ & $\begin{array}{r}8.03 \\
72.80 \\
80.83\end{array}$ \\
\hline $\begin{array}{l}\text { Inner reef } \\
\text { platform }\end{array}$ & $\begin{array}{l}\text { E. mathaei } \\
\text { E. aciculatus }\end{array}$ & $\begin{array}{l}6.50 \\
1.05\end{array}$ & $\begin{array}{l}80.0 \\
33.3\end{array}$ & $\begin{array}{l}1.90 \\
1.80\end{array}$ & $\begin{array}{r}200 \\
54\end{array}$ & $\begin{array}{l}.1130 \\
.1771\end{array}$ & $\begin{array}{r}268.10 \\
67.87 \\
335.97\end{array}$ \\
\hline $\begin{array}{l}\text { Outer reef } \\
\text { platform }\end{array}$ & $\begin{array}{l}\text { E. mathaei } \\
\text { E. aciculatus }\end{array}$ & $\begin{array}{l}1.75 \\
0.66\end{array}$ & $\begin{array}{l}53.0 \\
34.3\end{array}$ & $\begin{array}{l}1.95 \\
1.68\end{array}$ & $\begin{array}{l}58 \\
21\end{array}$ & $\begin{array}{l}.1166 \\
.1508\end{array}$ & $\begin{array}{r}74.50 \\
36.25 \\
110.75\end{array}$ \\
\hline
\end{tabular}

* \% frequency $=\frac{\text { no. of quadrats with species } X}{\text { total no. of quadrats. }} \times 100$ 
Project: Observations and identifications of algal specimens collected from the seaward turf zones

Investigator: K. E. Schlech

Department of Botany

University of Hawaii

Marlin Atkinson

Department of Oceanography

University of Hawaii

Honolulu, Hawaii 96822

Objectives: $\quad 1$. To obtain reproductive material algal specimens of the seaward reef flats.

2. To extend taxonomic data on the composition of these communities.

The following is a preliminary list of the genera collected at Enewetak Atoll. Species identification will subsequently be made and a species list made (see Table 1 ).

Due to inclement weather and vehicle problems sampling the algal turf on the seaward reefs was not possible.

Specimens were collected from the Quarry and although this is not a natural community, it provides some indication as to the diversity of the algae on these seaward reefs. Most of the Rhodophycean material was not fertile, though some was tetrasporic, and it is felt that as some seasonality may exist, collections made during the spring months (or January-April) may provide more fertile specimens. The composition of the seaward community appears to be considerably more diverse than the communities sampled in the lagoon.

Lagoon samples were obtained from two different community types. One type may be characterized as patch reef (between 20-50 ft.) with a sandy floor; such as those off Medren, Ananij and Mut. Within these patch reefs most of the algal specimens are found growing epiphytically on coral heads, and are not well developed. The other zone that was observed may be described as a shallow (6-10) area, such as those found adjacent to the islands of Biken, Mut and Ikuren. These areas, containing mixed sand and rubble substrata, formed well developed communities of Caulerpa, Halimeda, Dictyota and Neomeris sps. Several Asparagopsis communities were observed and the distribution of this alga was noted as it appears to form different patterns depending on its location.

At Mut Island, on the rubble flat, the Asparagopsis growth precisely paralle 1 s the beach front in a strip about a meter wide and several hundred meters in length. In deeper water, however, the alga forms an abundant but scattered community, and i.t. vertical distribution extended to at least 70 feet and appeared to be fairly well established at that depth. 
The blue green algal populations were extensive and the lagoon provides an excellent variety and abundance of Cyanophytes for study. More taxonomic, physiological and ecological work is needed concerning the Cyanophyta. Recently much interest has been generated in the toxic properties of the blue green algae, and as toxic fish have been reported from the lagoon, in situ chemical analyses of the different representatives could contribute greatly to this area of research.

One specimen has been collected which has not previously been reported from the Marshalls. Although it is included by some (Hardy-Halos) in the genus Neomonospora pedicellata (Smith) G. Feldman, it is felt that this specimen is distinct from Neomonospora and it has been identified and tentatively confirmed as Corynospora (Rhodophyta). The material is tetrasporic and the description of the tetrasporophyte is being worked on at present.

Table 1

\begin{tabular}{llll}
\hline Cyanophyta & Chlorophyta & Phaeophyta & Rhodophyta \\
Lyngbya & Halimeda & Ectocarpus & \\
Symploca & Caulerpa & Sphacelaria & Hypnea \\
Rivularia & Neomeris & Dictyota & Tolypiocladia \\
& Tydemannia & Padina & Acrochaetium \\
& Avrainviliea & Thrbinaria & Falkenbergia \\
& Bryopsis & & Botrycladia \\
Rhipilia & & Champia \\
Udotea & & Wrangelia \\
Acetabularia & & Ceramizo \\
& & Spyridia \\
& & Chondria \\
& & Heterosiphonia \\
& & Corynospora \\
& & Gelidiopsis \\
& & Griffithsia \\
& & Rhodymenia \\
& & Gelidium
\end{tabular}


Project:

Investigators:

Objective:
Diurnal cycles in reef flat calcification activity on Johnston Atoll

Stephen V. Smith

Donald W. Kinsey

Clark R. Lewis

Hawaii Institute of Marine Biology

P. 0. Box 1346

Kaneohe, Hawaii 96744

To establish the $\mathrm{CaCO}_{3}$ production rate in a shoal-water, regionally extensive environment characterized by extreme coral cover and high water motion.

Smith and Kinsey (1976, Science) postulated that coral reef growth is characterized by an upper limitation of the reef $\mathrm{CaCO}_{3}$ production to a rate of about $4 \mathrm{~kg} \mathrm{CaCO} \mathrm{m}^{-2} \mathrm{yr}^{-1}$. Smith and Harrison (1977, Science) considered, for the first time, a sloping forereef situation at Enewetak. This environment has usually been proposed as the ultimate zone of rapid reef growth, or at least of high reef calcification rates. They found that it fell short of the $4 \mathrm{~kg}$ "maximum." Further, Kinsey (1976 in LIMER team report, Search) reported a seaward shallow-depth zone of extreme coral cover and even this environment was found to calcify right at the $4 \mathrm{~kg}$ rate. Davies and Kinsey (1977) extended the postulate to suggest that the $4 \mathrm{~kg} \mathrm{~m} \mathrm{~m}^{-2} \mathrm{yr}^{-1}$ limit applied over the whole period of Holocene reef growth even though the depth of water cover was mostly in excess of that presently occurring. All the above findings relate to Pacific reefs.

In contradiction to these studies, several papers in the 1977 Proceedings, Third Coral Reef Symposium report Holocene accretion rates in Caribbean reefs which imply calcification rates of $10 \mathrm{~kg} \mathrm{~m}^{-2} \mathrm{yr}^{-1}$ or more. However, these estimates were based on interpretation of the stratigraphic record, as opposed to the chemical rate approach used in the Pacific studies, and may reflect procedural differences.

Johnston Atoll was used in the present study as it included one of the most extensive areas of nearly total coral cover of any reef known to us. This area is under an average depth of several meters of water and as such might be expected to resemble to some degree the condition applying commonly on most reefs during much of the Holocene Transgression. However, it does exhibit one major difference from an early Holocene reef in that there is a developed surface perimeter reef around the leeward side of the total platform. There is no surface reef in the conventional position around the seaward edge but the leeward reef flat does contribute a degree of protection from the more violent physical componcrito of watar motion. 
Five sites were used for the study of calcification rates using the chemical approach. Each was chosen either because it represented a realistic comparison to sites on other reefs for which data were already available, or because it represented a marked exception to those zones normally occurring on present day coral reefs (i.e., the deeper, high coral cover areas). The findings for each of these sites will be considered separately.

Site 1 - A shallow (2-4 m) area of extensive line reefs just south of Sand Island. Extensive sandy bottom with relatively low coral cover. A very close analogy to the lagoon zone of reticulated reefs at One Tree Island reported by Kinsey, 1977 (Third Coral Reef Symposium). Probably a reasonable analogy for much of the lagoon at Fanning Atoll reported by Smith and Pesret, 1974 (Pacific Science)

\section{Calcification estimate}

$$
\left(\mathrm{kgCACO}_{3} \mathrm{~m}^{-2} \mathrm{yr}^{-1}\right)
$$

One Tree Island, reticulated lagoon

1.5

Fanning Atoll, lagoon

1.0

Johnston Atoll, Site 1

1.6

Site 2 - A slightly deeper (3.3 m) slightly sparser area similar to the above, but with less lineation in the reefs. Slightly SW of East Island. The same analogies can be made.

$\frac{\text { Calcification estimate }}{\left(\mathrm{kgCeCO} \mathrm{m}^{-2} \mathrm{yr}^{-1}\right)}$

One Tree Island, reticulated lagoon

1.5

Fanning Atoll, lagoon

Johnston Atoll, Site 2

1.0

1.3

Site 3 - This is the very extensive area east of North Island which is a somewhat more exposed version of site 5. Unfortunately, the data at this stage of processing have not been of adequate reliability to report at this time. This is most unfortunate as this site really was to have been the ultimate test of the "upper limit" postulate.

Site 4-Reef flat ( $<1 \mathrm{~m}$ deep) north of Johnston Island. Continuous algal platform with very sparse corals, few foliose algae but extensive encrusting coralline algal cover. Typical of most algal crest areas on any reef but unlike all those previously reported, has a leeward aspect for at least some of the year. Many general analogies can be found in the literature. 


\section{Calcification estimate}

$\begin{array}{ll}\text { One Tree Island, algal crust } & 4 \\ \text { One Tree Island, main reef flat } & 4.5 \\ \text { Enewetak reef flat, coralgal (Smith) } & 4 \\ \text { Enewetak reef flat, algal (Smith) } & 4 \\ \text { Lizard Island reef flat, coralgal (Kinsey) } & 3.6 \\ \text { Lizard Island reef flat, algal crest (Kinsey) } & 3.8 \\ \text { Johnston Atoll, site } 4 & 4.4\end{array}$

To this point it is obvious that (1) Johnston Atoll reef systems compare very closely with those on more "conventional" reefs where equivalent zones can be found, (2) a leeward reef-flat is calcifying at precisely the usual rate of seaward reef-flats, (3) the general $4 \mathrm{~kg}$ limit has not been appreciably exceeded.

Site 5 - Extensive area of very high coral cover on small anastomosing approximately conical pinnacles west of North Island. Very little open sandy bottom. Bottom depth $4-5 \mathrm{~m}$. No reasonable analogy known.

\section{Calcification estimate $\left(\mathrm{kgCaCO}_{3} \mathrm{~m}^{-2} \mathrm{yr}^{-1}\right)$}

\section{Johnston Atoll, site 5}

Clearly this environment is calcifying at approximately double the previously postulated upper limit, thus establishing beyond any reasonable doubt that areally extensive exceptions to our concept of limitation do occur, and may well have occurred during the Holocene Transgression. The principal extenuating circumstance in the present case is the presence of the closely adjacent leeward crest area which may allow a relatively uniquely different situation to develop. There is now an obvious need to seek out the frequency of exceptions of this kind and to look cautiously on theories of Holocene reef growth which assume absolute constancy of maximum calcification ratc. 
Project: Diagenesis and pore evolution of the reef plate:

Enewetak Atoll

Investigators: Burr A. Silver

Alan Emmendorfer

Marty Reis

Department of Geology

University of Oklahoma

Norman, Oklahoma 73069

Objectives: $\quad$ 1. To establish porosity and permeability values of the reef plate.

2. To compare present pore geometry with ancient pore geometry.

3. To measure pore fluid chemistry within the reef plate.

4. To interpret the diagenet1c history of the reef plate within an atoll.

A Winkie GW-15 portable core rig was mounted on a rebuilt paint barge that was provided by the U. S. Navy. A total of 27 core sites were drilled at 12 different locations on Enewetak, Rojoa and Mui islands (see Table 1). Exact locations of the core sites will be submitted to MPML as soon as we complete plotting them on aerial photographs that have been requested from the U. S. Air Force. About 212 feet of hole was cored and a total of 115 of core was recovered. The core material is $1-1 / 2$ inch in diameter.

Hand-specimen description of the 115 feet of core has been recorded on strip logs at a scale of $1 \mathrm{~cm}=5 \mathrm{~cm}$. Samples for porosity and permeability analysis are being selected during this phase of sample analysis. Pore geometry analysis will be initiated by October 1978 after the delivery if impregnation equipment which is now on order. The phase of the study will involve impregnating selected cores at each site with plastic. The $\mathrm{CaCO}_{3}$ will then be dissolved and the resultant pore geometry studied by petrographic and SËM analysis. 
Table 1

\begin{tabular}{|c|c|c|c|c|}
\hline $\begin{array}{c}\text { Site } \\
\text { Location }\end{array}$ & $\begin{array}{c}\text { Core } \\
\text { Number }\end{array}$ & $\begin{array}{l}\text { Total } \\
\text { Depth }\end{array}$ & $\begin{array}{c}\text { Core } \\
\text { Recovery }\end{array}$ & $\begin{array}{l}\text { Percent } \\
\text { Recovery }\end{array}$ \\
\hline Enewe tak & $\begin{array}{l}\text { F1A } \\
\text { F2A } \\
\text { F2B } \\
\text { F3A } \\
\text { F3B } \\
\text { F4A } \\
\text { F5A } \\
\text { F5C } \\
\text { F6A }\end{array}$ & $\begin{array}{c}2.5 \\
4.5 \\
4.5 \\
5.0 \\
4.5 \\
6.0 \\
5.0 \\
5.0 \\
12.25\end{array}$ & $\begin{array}{l}0.75 \\
3.5 \\
3.25 \\
2.0 \\
3.25 \\
5.3 \\
4.5 \\
3.25 \\
6.25\end{array}$ & $\begin{array}{l}30 \\
77 \\
72 \\
40 \\
72 \\
88 \\
90 \\
65 \\
51\end{array}$ \\
\hline Rojoa & $\begin{array}{l}\text { U1A } \\
\text { U1B } \\
\text { U1C } \\
\text { U2A } \\
\text { U2B } \\
\text { U2C } \\
\text { U3A } \\
\text { U3B } \\
\text { U3C } \\
\text { U4A } \\
\text { U4B } \\
\text { U4C } \\
\text { U5A } \\
\text { U5B } \\
\text { U5C }\end{array}$ & $\begin{array}{r}17.0 \\
6.0 \\
6.0 \\
22.0 \\
5.2 \\
5.3 \\
11.0 \\
7.0 \\
7.0 \\
22.0 \\
5.0 \\
17.0 \\
7.0 \\
5.0 \\
5.0\end{array}$ & $\begin{array}{l}3.0 \\
1.0 \\
1.5 \\
4.5 \\
4.0 \\
4.5 \\
5.2 \\
4.0 \\
6.75 \\
16.0 \\
4.5 \\
7.0 \\
5.0 \\
4.6 \\
4.5\end{array}$ & $\begin{array}{l}18 \\
17 \\
25 \\
20 \\
77 \\
84 \\
47 \\
57 \\
96 \\
72 \\
90 \\
41 \\
71 \\
92 \\
90\end{array}$ \\
\hline Mui & $\begin{array}{l}\mathrm{HIA} \\
\mathrm{H} I \mathrm{~B} \\
\mathrm{HIC}\end{array}$ & $\begin{array}{l}5.0 \\
5.2 \\
5.0\end{array}$ & $\begin{array}{l}3.0 \\
2.0 \\
2.5\end{array}$ & $\begin{array}{l}60 \\
38 \\
50\end{array}$ \\
\hline Totals & & 212.25 & 115.85 & \\
\hline
\end{tabular}


Project: $\quad$ Effect of shade on coral reef community structure

Investigators: John Stimson

Tom Polacheck

Department of Zoology

University of Hawaii

Honolulu, Hawaii 96822

Objective: To determine how shading by canopy-forming corals influences recruitment of young corals and survival of newly shaded corals.

The calcification rate of corals is known to be affected by the amount of light energy and the distribution of individuals of particular species is thought to be determined at least in part by light energy, but there is little experimental work on this subject. Quantitative surveys of corals at Enewetak show that where light levels are reduced as a result of shading by table Acropora,coral densities are very much lower than on adjacent unshaded areas (Table 1 ).

Table 1. Density of corals under live and dead table Acropora of approximate $1 \mathrm{~m}$ diameter and in control areas of $1 \times 1 \mathrm{~m}$.

\begin{tabular}{lrr}
\hline Site & Shade & Unshaded Control Area \\
\hline & & \\
A & 3.23 & 22.0 \\
B & 10.36 & 39.0 \\
C & 15.28 & 36.0 \\
D & 7.32 & 27.0 \\
E & 3.90 & 23.0 \\
F & 6.68 & 32.0 \\
& & \\
\hline
\end{tabular}

Additionally, corals which occur in the shade are primarily of the genera StyZocoenielza, Montipora, Seriatopora and various massive species. The predominant species in the adjacent unshaded areas are of the genera Acropora and PocizZopora.

These results suggest that some species of corals: (1) avoid shade when settling, (2) do not survive in the shade once overtopped by the fast growing table Acropora, or (3) that some species prefer the shaded over the unshaded areas. Some coral species may be classified as shade intolerant and some shade tolerant as is done in forest communities, and coral communities may be structured in large part by this factor when canopy forming corals are present. 
Experiments were set up in summer 1977 and summer 1978 to examine the influence of shade on coral growth and survival. Shade producing structures were set up in August 1977 and 1978 which mimicked the size and height of table Acropora. They were cement discs $80 \mathrm{~cm}$ in diameter, supported by four legs. The artificial table Acropora erected in summer 1977 were destroyed by a winter storm, and new ones of an improved design were erected in 1978 .

Additionally an experiment was initiated in 1978 to determine the survivorship of corals placed in the shade of table Acropora and in adjacent control areas. Specimens of nine species were collected split in half and one piece assigned to the shade treatment and one to the open. The experiment was replicated 18 times. 


\author{
Project: Bird populations on Enewetak Atoll \\ Investigator: Manfred Temme \\ Environmental Studies Center \\ Bowling Green State University \\ Bowling Green, Ohio 43403
}

Objectives:

1. To document differences in bird populations between current conditions and the conditions noted in November 1977.

2. To document additional information on migratory species, as well as the breeding status of resident birds.

Ornithological observations were made incidental to rodent research activities on the Enewetak Atoll from March 21 through April 12, 1978. This period overlaps the onset of the migration season. In contrast with the findings on a trip to Enewetak Atoll in November 1977, Noddy Terns were breeding. Five additional islets were visited. Two of these islets are considered major sites for bird populations.

In comparison to the observations made on the November 1977 trip, a few changes were observed. The brush piles on Enjebi islet had been burned. While this had changed the interior cover of the islet considerably, growth of vegetation bulldozed away prior to November 1977 had started.

The interior of Runit islet had been changed. Most of the larger bushes (Scaevola taccada and Messerschmidia argentea) adjacent to the crater at the north end of the islet and north of the bunker had been cut away. The islet is now a major site of cleanup operations. On Medren, which was visited the first time by me, the situation was similar.

The vegetation (Scaevola taccada, Messerschmidia argentea) around the fringes of many of the islets had either dead leaves or was totally defoliated. On tiny islets the whole vegetation zone was affected. There is strong evidence that the two typhoons, which had hit the atoll during the Christmas week 1977 and in the second week of January 1978, were responsible for the dying of these plants. A closer look at this impact on the islets Ribewon and Kidrenen showed that high waves had breached the islets, uprooted many bushes, and deposited drift material. Also here many scrubs were found dead, among them Suriana maritama and Pemphis aciduza. 


\section{Species Account}

Emphasis is given on this account on the differences between the findings on the previous trip (November 7-23, 1977) and the conditions found on this expedition. The paper discusses further findings about rare and difficult to identify migratory species, as well as the breeding status of the resident birds. Data are summarized in Table I.

Puffinus pacificus: The area on Bijire islet where a colony of about 50 pairs of the Wedge-tailed Shearwaters had been found in November 1977 was visited again on March 23, 1978. All holes appeared old and were partly caved in. Some entrances were partly filled with dried leaves; others, closed by cobwebs. On a subsequent visit of the area on April 8, some of the holes looked reopened. Footprints indicated visits of the burrows by the birds; three birds were pulled out, banded and returned to the burrows. We were witnessing the arrival of the first breeding birds in their colony. The schedule of the Shearwaters on this atoll agrees with that on the Hawaiian Islands (Shallenberger, 1975) arriving in March, laying their single egg in June, and the chicks leaving the colonies in November. The latter had been found on Bijire in 1977.

Phaeton mubicauda: Two islets visited (Bokolua and Mijikadrek) had breeding populations of this species. Red-tailed Tropicbirds were extremely abundant on Bokoluo, with an estimated 45 breeding pairs. Seventeen juvenile birds were banded. Several adult birds were seen incubating their eggs. Interestingly, the nest sites were not found exclusively along the northeast-facing beaches, where the tradewinds could support the adults for taking easier flights. Nests were found on any part of the islet, often not far away from the existing $50 x$ $50 \mathrm{~m}$ swath gird, bulldozed in late 1977. This apparently provided some free space for birds taking off. We were told by military personnel that incubating females and their nests were physically moved from the paths of the bulldozers. According to the estimates of Dr. Jackson, Mijikadrek islet has a breeding population of about 20 pairs; the nests were located near the windward beach. Here, six juvenile birds were banded. Single bịds have been noted over the islets Lojwa, Ribewon and Kidrenen.

Banding Records

\begin{tabular}{lccc}
\hline Islet & Date 1978 & Number of Birds & $\begin{array}{c}\text { Number of } \\
\text { Birds Banded }\end{array}$ \\
\hline \multirow{2}{*}{ Bokolua } & April 8 & $495-47404-49547415$ & 6 \\
Mijikadrek & April 8 & $724-00171-42400182$ & 12 \\
& & $495-47409-49547414$ & 6
\end{tabular}


Sula sula: The booby roosting site on Ribewon islet was visited on April 11. It was estimated that about 250 immature and subadult Red-footed Boobies roosted that night together with about 100 immature and subadult Brown Boobies and Greater Frigatebirds. The birds occupied, as in previous years, dense Scaevola taccada scrub predominantly at the periphery and the southern tip of the islet. At this time, however, many of the bushes were defoliated. To what extent the excrement of the birds or the typhoon had defoliated the bushes was not determined.

Two immature Red-footed Boobies roosted on Bokoluo islet in company of Frigate birds, and 20 Boobies were seen later on Biken.

Sula Zeucogaster: Breeding of Brown Boobies on Ribewon islet must be a relatively recent occurrence. Bastian (field notes) in 1976 found 10 nests and suspected a few more. The islet had been visited by him in the second week of March, and he had found three nests with eggs and the rest with newly hatched or downy young. This indicates that the birds had started incubation earlier than found this year. On April 7, 15 nests were found ( 4 with a single egg, the rest contained two eggs each). Only in one nest was one newly hatched young seen. All Brown Boobies had their nests built on the east-facing side of the islet (towards the lagoon). Two nests were constructed on elevated portions on the beach in drift material; most of the others were on the grassy ledge of 1slet margin, and some were further inland $(20$ to $25 \mathrm{~m}$ ). Upon my arrival the birds first regurgitated fish (in one case a large flying fish) to reduce weight before taking flight. Then the birds ran with spread wings until they were able to take off. If approached directly upwind, the birds sometimes would remain on the nest. The number of breeding pairs is estimated to be 20 . About 100 immature and subadult Boobies of this species were roosting in company of Red-footed Boobies and Frigatebirds in the scrub vegetation. Species numbers vary in other observations, and in some years parties failed to observe Boobies at all. Carpenter et al. (1968) give a full account on these varying reports. Two specimens of this species also were seen on a sandbar of Bokoluo islet.

Fregata minor: As in previous years, single or small groups of immature Great Frigatebirds were seen flying over several islets (Table I). When the islet of Bokoluo was visited, an estimated 100 immature Frigates were observed. Among these only several subadult birds were recognizable. The birds apparently use this islet only for roosting. No evidence of nesting was found. Most of the roosting trees, located at the northwest end of the islet, were defoliated and scattered over a grassy opening. Only four Boobies were seen in this roosing community.

The traditional roosting islets for Frigatebirds, Ribewon and Libiron were visited on April 10 for an overnight stay. As reported by other observers (Woodbury, 1962; Pearson and Knudsen, 1967, Carpenter et al., 1968) large flocks of about 400 Frigatebirds were estimated to 
roost. At our arrival the birds took off from their roosting trees, located mainly at the south tip of the islet, and started to soar. About $20 \%$ were estimated subadult males, and probably the same proportion was subadult females; the rest were determined to be immature birds. Also no evidence of breeding was found.

Sterna sumatrana: Black-naped Terns have been observed at six different islets. They are seen usually singly or in small groups passing along the islets or at rest on bunkers on the beach. Occasionally small flocks of 10 to 25 birds were seen fishing in company of a few Black Noddy Terns. Because Blacknaped Terns appear very white at some distance over the lagoon, not all were distinguishable from Fairy Terns and were not counted.

Stema fuscata: Immediately after arrival on Aomon the breeding site of this species was visited. The Sooty Terns had been observed building up to a colony of about 5,000 pairs in the second week of November 1977. At the time of this visit most of the young were fledged and seen flying with adults along other islets. The estimate of the birds, including the adults and immatures still present, amounted to about 5,000 .

Flocks of about 200 immature birds apparently had been lead away by the adult birds from the main breeding ground into Lepturus repens plains northeast of the main colony. In the center of the main colony two nests with eggs were found, and one adult bird huddled one fiveday old chick. About five half-grown chicks were seen running about.

A small subcolony had been formed recently. Roughly 20 nests containing one egg each were found at the southwest periphery of the old colony. It was noted that the adult terns had lost their "tameness," and it was difficult to approach them as closely as earlier in the season. This made catching even the incubating birds with a dipnet difficult. Therefore, we concentrated on catching some of the almost-fledged birds and banded 54 of them.

Banding Recọds

\begin{tabular}{lccc}
\hline Islet & Date 1978 & Number of Bands & $\begin{array}{c}\text { Number of } \\
\text { Birds Banded }\end{array}$ \\
\hline \multirow{2}{*}{ Aomon } & April 7 & $1033-66601-1033-66633$ & 33 \\
& April 8 & $1033-66642-1033-66653$ & 12 \\
& April 22 & $1033-66850-1033-66858$ & 9 \\
& & Total birdsibanded: & 54
\end{tabular}


About 50 immature birds had some kind of wing problem and were not able to take to the air. The birds were not able to extend either wing to full length. The wing washeld in an awkward downward angle, and when pursued the bird made frantic flapping movement. The birds tried to run away and to hide under Scaevola taccada bushes. It is speculated that these birds received injuries, inflicted when young birds entered nesting territories of neighboring adults, by being pecked at their still small and fragile wings. Hypotheses by some military personnel that these injuries came about by exposure to radiation have been rejected by us.

Presumably, because of the presence of the large colony on Aomon islet some Sooty Terns passed by each islet visited by us. Since it was not meaningful to record each Sooty Tern passing by or flying over the lagoon, small flocks or single birds were not always recorded (Table I). Especially on the neighboring islets of Aomon, Bijire and Lojwa, Sooty Terns on their way to fishing grounds passed by almost constantly; recording of these birds would have provided misleading figures. However, birds seen on the western and northwestern half of the atoll have been noted if in sufficient numbers.

Sterna bergii: Each time the party passed by Medren the offshore fenceposts were checked for resting Crested Terns, as in November 1977. Mostly there were two to three birds, but on 3 April nine birds were counted, among them a few subadults. Most of the Crested Terns seen at different islets were silent, but the one seen on Ikuren uttered the alarm call when seeing the observers.

Anous stolidus: In comparison to the observations in November 1977, when no large breeding aggregations were found, this time seemed to be the peak of the breeding season. On most of the more undisturbed islets visited breeding Common Noddy Terns were noted.

On Enjebi about 50\% of the eggs had hatched in the nests inspected. On the islets of Bokoluo and Ribewon about $80 \%$ of the nests contained young, many already about two weeks old. On Bijire, on the other hand, only eggs were found.

In general, slightly larger proportions of Tern nests inspected were on the ground rather than in low Messerschmidia argentea trees. On Ribewon, many nests with young were found on the lagoon beach side in drift material. On the northside of the islet Common Noddies had nests in large Pemphis bushes about $2.5 \mathrm{~m}$ above the ground. Most of these bushes had apparently been killed by the typhoons in Decmeber 1977 and January 1978 but still provided dense cover and support for the simple aggregation of nesting material:

On Enjebi, in contrast to Ribewon, most birds bred on the grassy plains of the island. This was also true on Jimini islet. This islet. inspected briefly on March 28, has 100 breeding pairs of this species. 
Shortly before this visit the eggs of all pairs had been taken and eaten at a campfire, presumably by the Japtan islet inhabitants.

The following number of Common Noddy Terns were banded:

Banding Records

\begin{tabular}{llcc}
\hline Islet & Date 1978 & Number of Bands & $\begin{array}{c}\text { Number of } \\
\text { Birds Banded }\end{array}$ \\
\hline Aomon & April 8 & $1033-66634-1033-66641$ & 8 \\
Bokoluo & April 8 & $1033-66654-1033-66655$ & 2 \\
Ribewon & April 10 & $1033-66656-1033-66680$ & 25 \\
Kidrenen & April 11 & $1033-66801-1033-66803$ & 3 \\
Boken & April 22 & $1033-66883-1033-66897$ & \\
& & $1033-66685-1033-66695$ & 27 \\
& & Total birds banded: & 65
\end{tabular}

Anous tenuirostris: The Black Noddy on these low coral islets is a true tree-breeding species. Therefore the more forested islets had the large colonies. This species apparently has a more synchronized breeding pattern than the Common Noddy. Most of the nests seen, especially on the islets of Bokoluo and Ribewon, contained one to two week old chicks guarded by one parent. Large Messerschmidia argentea trees on Ribewon and also some Pisonia grandis trees on Bokoluo contained up to 20 nests in close proximity to each other. Large numbers (about 3,500 ) were recorded by $R$. K. Bastian for Biken islet. Total estimates of breeding pairs on all islets visited reach the range reported by Carpenter et al. (1968) (Table I).

Lack of rats on the islets of Bokoluo and Ribewon makes survival of chicks which had fallen from the nest possible. Apparently they. were still taken care of by their parents either on the forest floor or while standing on low branches.

During the observation period in November 1977 flocks of 30 to 60 Noddies had been seen regularly at several locations fishing together in the lagoon. Almost every day a flock of about 50 birds fished near Enewetak in November 1977. This year no such flocks were noted. Terns may fish to some extent for squid at night, since several remains were found under Black Noddy nests. Ashmole and Ashmole (1968) found on the Christmas Island that $5 \%$ of the total diet consists of squid. 
Number of banded Black Noddy Terns:

\section{Banding Records}

\begin{tabular}{|c|c|c|c|}
\hline Islet & Date 1978 & Number of Bands & $\begin{array}{c}\text { Number of } \\
\text { Birds Banded }\end{array}$ \\
\hline Aomon & April 8 & $592-32201-592-32204$ & 4 \\
\hline Bokoluo & Apri1 8 & $592-32205-592-32208$ & 4 \\
\hline Ribewon & April 10 & $\begin{array}{r}592-32222-592-32225 \\
592-32230\end{array}$ & $\begin{array}{l}4 \\
1\end{array}$ \\
\hline Boken & April 22 & $\begin{array}{l}1033-66696-1033-66697 \\
1033-66699-1033-66700 \\
1033-66898-1033-66900\end{array}$ & $\begin{array}{l}2 \\
2 \\
3\end{array}$ \\
\hline & & Total birds banded: & 19 \\
\hline
\end{tabular}

Gygis alba: Fairy Terns also were found breeding during this time. The found breeding sites usually contained a single egg. On Bokuluo, however, an almost-fledged young. was seen; and on Ribewon one chick, only a few days old, was walking around on the forest floor. After banding this young bird, it. was placed on a branch. By the next morning it had moved $3 \mathrm{~m}$ toward the tip of the branch. Bokoluo, Ribewon and Biken had the largest aggregations of Fairy Terns (Table I).

Egretta sacra: As in previous years on most of the islet visited a few Reef Herons were noted on reefs (Table I) Especially common were the Reef Herons on Runit, where the only nest, containing three eggs, was found. The nest was built almost on top of an older one in a small abandoned corrugated metal shed. As in November 1977, most herons sighted were dark gray (11 or $48 \%$ ); the rest ( 6 or $26 \%$ ) were white or $(6$ or $26 \%$ ) were mottled.

Anas sp.: On March 25 one small duck was flushed at one of the shallow freshwater ponds on Aomon. Since the duck was only seen for a brief moment and only the underparts were visible, it was not possible to identify it to species. The uniformly grayish belly and the size suggest that the duck may have been a female Gargany (Ants querquedula). Granted this identification is right, it would be the first sighting of a Garganey on the Marshall Islands. In the Philippines, for instance, this species is a very common migrant and winter visitor (Teme; 1976). 
Pluvialis dominica: Golden Plovers had, at the onset of their prenuptial migration period, definitely increased in numbers in comparison to the sightings in November 1977. Almost every islet had a good population, especially the larger islets with larger reefs (Table I). During the first days after the arrival of the party on the atoll the number of Plovers which had already completely changed into the breeding plumage was estimated to be approximately $20 \%$. In the second week of April the number of birds in the breeding plumage had increased to about $40 \%$.

One Golden Plover in breeding plumage was caught by hand at night in the middle of the forested area on the islet Ribewon and was banded.

\section{Banding Record}

\begin{tabular}{llcc}
\hline Islet & Date 1978 & Number of Band & \multicolumn{2}{c}{$\begin{array}{c}\text { Number of } \\
\text { Birds Banded }\end{array}$} \\
\hline Ribewon & April 10 & $592-3220426$ & 1
\end{tabular}

Numenius phaeopus: The sightings of Wimbrels during this trip period tremendously increased (Table I) in contrast to the observations in November 1977. On Enewetak alone up to eight Wimbrels often were found on the taxiways and grass strips along the runway of the airport. Their increase may be due to the onset of the migratory season. In contrast to the Bristle-thighed Curlew, this species frequented the reef of the islets for food gathering.

Numenius tahitiensis: The Bristle-thighed Curlew also had increased in numbers since November 1977 and was observed on most of the islets (Table I). This species is found more on the islets in grassy plains and denser vegetation than the Wimbrel. Often birds would walk into shrubby and even forested areas, come out at some openings along the beaches, and walk back into the vegetation again. On Enjebi Bristle-thighed Curlews were seen to walk among the parasitic vines (Cassytha filiformis) to feed on the small round fruits. Another common behavior of $N$. tahitiensis was the perching on posts, bunkers, sandpiles, and other elevated structures.

Tringa glareola: On November 9 and 21, 1977 a Wood Sandpiper had been sighted on Aomon islet. This represented the first record of this migrant species for the Marshall Islands (Report, 1977). Aomon is the only one of 40 islets in the atoll with freshwater ponds, created by bulldozing in 1972. These shallow, rain-filled ponds, are scattered over about 6 hectares of the islet's 40, and now have some marginal vegetation. Aomon was visited again on March 24 and 25. One Wood Sandpiper still frequented 
the small fresh water ponds; the next day two were seen and heard. Final visits to Aomon Islet were made on April 7 and 8 . On both days Wood Sandpipers were observed, and on April 8 three individuals were present. One bird was relatively shy; the other two allowed closer human approach. While I made documentary photographs, the other members of the expedition, W. B. Jackson, S. Vessey and T. Denbow observed the birds (Figure 1). The birds were seen in company of a few Sharp-tailed Sandpipers (Calidris acuminata), many Golden Plovers (Pluvialis dominica), and several Ruddy Turnstones (Arenaria interpres). When flushed, the birds uttered clearly the characteristic calls, facilitating the exact identification.

This species previously has been reported only from western Micronesica. In Guam and the Marianas it is considered an uncommon visitor (Baker, 1951; Mayr, 1945). Woodbury (1962), Amerson (1969), Carpenter et al. (1968), and Peason and Knudson (1967) did not mention any sightings of Tringa glareola on the Enewetak Atoll or other atolls of the Marshall Islands. The Wood Sandpiper, a very common migrant in Southeast Asia, also has been reported in great numbers from the Philippine Islands (McClure, 1974; Delacour and Mayr, 1946; DuPont, 1971; Temme, 1974). The Enewetak sightings suggest that this species be considered an occasional visitor to the Marshall Islands, which apparently constitute the outermost eastern limit of the migration route and wintering areas.

The specimen originally sighted in November 1977 may have been over-wintering on the islet. The presence of Wood Sandpipers at Enewetak Atoll in the future will depend on the continued availability of freshwater on the low coral islet on Aomon.

Capella hardwickii: On March 25 and on April 7 one Snipe was flushed from the shallow fresh water ponds on Aomon islet. The difficulties in exact field identification of several similar looking Snipes are well known. I have experienced Capella gallinago for many years in Europe and $C$. gallinago and $C$. megala together for four years in the Philippines. I found that it is possible to distinguish both species in the field by their rasping call notes when flushed, though Mayr (1945) was not sure of this. The flushing calls heard on Aomon were definitely not those of $C$. megala. They were closer to $C$. gallinago, but appeared slightly harsher. The flight of the Snipe was not as zigzagging as is usually seen in $C$. gallinago. Heavier flight without "twisting" is mentioned by Yamashina (1961) as one character of $C$. hardwickii. This species would also be more likely to occur here; it would reach the Marshalls on its migration flight from Japan to Australia and New Zealand. This leads me to conclude that this species must have been the Latham Snipe.

A third Snipe was flushed on March 27 on the reefs of Bruce islet. This is an uncommon habitat for such a species. C. hardwickii has been recorded from the Marshall Islands before from Kwajalein '(Amerson, 1969). 
The Common Snipe (C. gallinago) has been reported only from Saipan in western Micronesia. There are records of the Swinhoe's Snipe (c. megala) from Guam and Palau, western Micronesia (Baker, 1951; Owen, 1977).

Heteroscelus inanum: The Wandering Tattler is a very common shorebird on most islets visited (Table I). Some observations suggest that this species is somewhat territorial during the wintering period, as has been observed in Brown Shrikes (Lanius cristata) (own observation). One bird, for instance, was relatively fearless of man and was seen often and regularly at the seawater quarry near the marine laboratory on Enewetak. It was doubtlessly always the same kind of bird that had occupied this area of reef. Other tattlers which wanted to land nearby were regularly chased away. Chases also were seen on reefs of some other islands.

Heteroscelus brevipes: Already Pearson and Knudson (1967) and Carpenter et al. (1968) suspected that the Gray-tailed Tattler occurred on this atoll. Pearsen and Knudsen (1967) actually heard differences in the call notes and noted differences in the plumage of two birds on Bijire and Medren.

Therefore, special attention was given to the differential call notes mentioned by several authors as identification aid (Falla et al., 1967; King and Dickinson, 1975). The note is described as a double whistle "too-weet" with the second syllable inflected, while $H$. incanus has a loud twittering of eight notes on almost the same level: I have heard the call of H.brevipes several times in the Philippines, where it is known to occur on small coral island (unpubl. notes). Pearson and Knudsen. (1967) also mentioned this double whistle which they heard on the Enewetak Atoll.

During this expedition almost every Tattler seen was slowly approached in order to flush it; usually the call note was uttered. Regularly two birds were met with on the reefs on Enewetak that ut tered the double note. Two other Tattlers at the fresh water pond on Aomon also uttered without doubt this call. Usually the other calls of the Wandering Tattler heard nearby made the differences between both notes more conspicuous. Often the same birds were flushed several times. A generally lighter gray of the plumage also was noted, as Pearson and Knudsen (1967) reported, but was later found not to be reliable for field identification. Based on the diversity of the call notes it is concluded that these callers are $H$. brevipes and that this species occurs in small numbers in the Marshalls.

Arenaria interpres: The Ruddy Turnstone is the most abundant migratory shorebird on the Enewetak Atoll (Table I). There was almost no islet found without Turnstones. In comparison to November 1977, numbers still had increased. Many individuals (40\%) showed a full breeding plumage. 
Calidris alba: The Sanderling is considered by Baker (1951) as a regular visitor to the eastern Marshalls. Woodbury (1962) saw only two individuals on March 13 and April 19. Since then apparently Sanderlings have not been reported again, which indicates that this species is not too common on Enewetak Atoll. One Sanderling in company with a Ruddy Turnstone was seen on March 26, 1978 at a rain puddle on the taxiway of the airport of Enewetak Island.

Calidris acuminata: Sharp-tailed Sandpipers were seen again at the fresh water ponds on Aomon on March 24, 25 and on April 7. and 8 (Table I). As in November 1977 this species usually was found in company of Turnstones, Golden Plovers and Wood Sandpipers.

Eudynamis taitensis: Two unverified observations of the Long-tailed Cuckoo from New Zealand were made in 1968 on Medren and one on Runit in 1971 (Jackson, unpubl. reports). On April 8, 1978 one Long-tailed Cuckoo was seen flying across a bulldozing clearing on Bokolu islet. 
TABLE I. Summary of bird spectes observed at Enewetak Atoll, March/April 1978.

\section{SPECIẼS}

Puffinus pacificus

Phaeton rubricauda $(80)$ *

Sula sula 2

Sula leucogaster. 2

Fregata minor $\quad 100$

Sterna sulliatrana

Sterna fuscata $\quad 50$

Sterna bergii 4

Anous stolidus $\quad$ (600)

Anous tenuirostris (1000)

Gygis alba (200)

Egretta seccra

Arias spp.

Pluvialis dominica 50

Numerius phaeopus 2

Numer.ius tahitiens is 12

Tringa glareola

Capella hardwickii

Heteroscelus brevipes

Heteroscelus incanus

Arenaria interpres.

Caliuris alba

Calidris accuminata

Eudynamis taitensis 1 okol uo Enjebi Mijikadrak Aomon Bijire Lojwa Runit Ananij Medren Enewetak Ikuren Ribewon Kidrenen Biken Jinimi

TOTAL

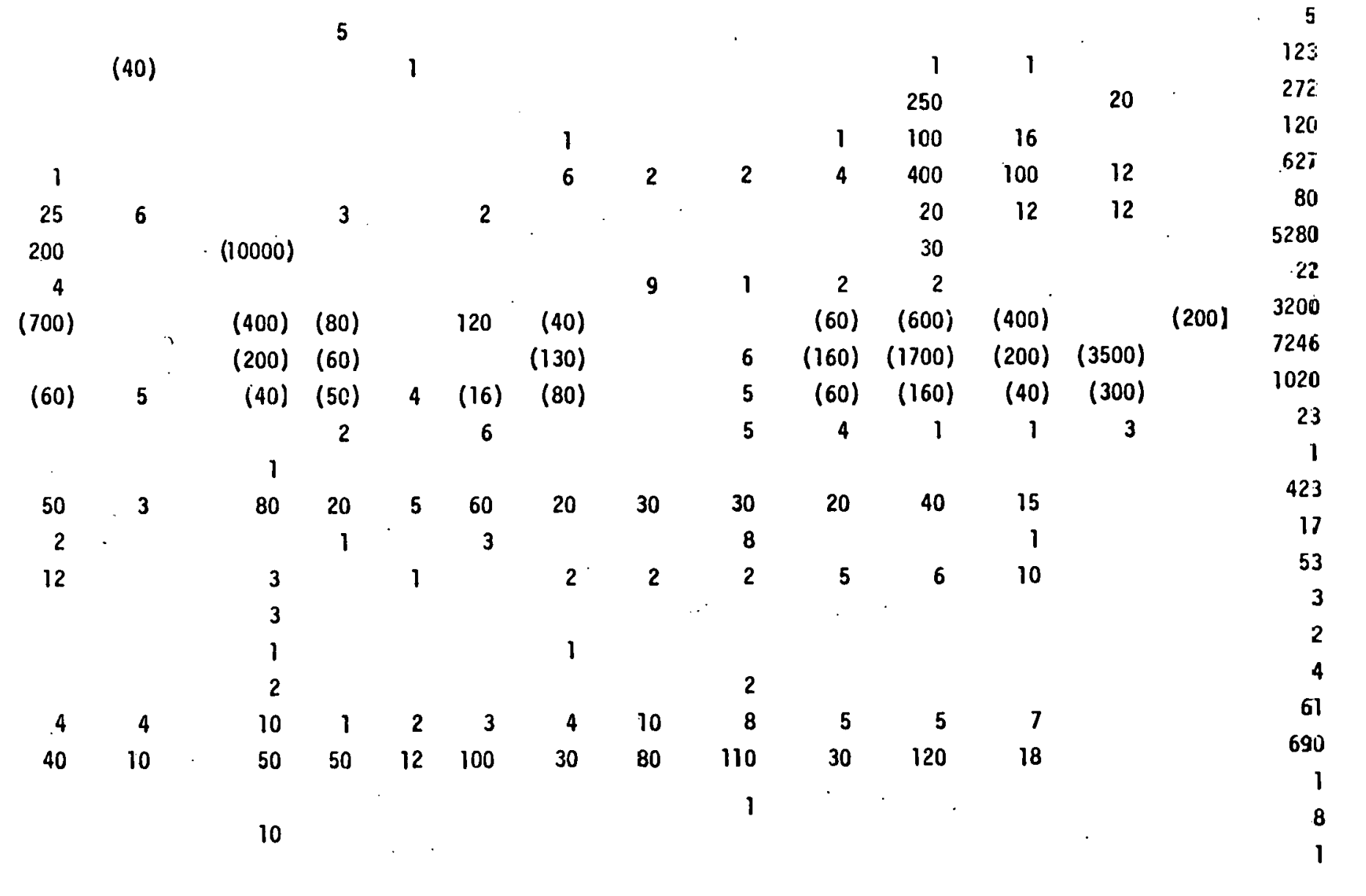

*Figures in parentheses indicate estimated number of birds existing as breeding pairs. 
FIGURE 1. PHOTOGRAPHS OF ENEWETAK ATOLL BIRDS

A. Wood Sandpiper (Tringa glareola) at a rainfed fresh water pond on Aomon islet ( 8 April 1978). This is one of the first records of Wood Sandpipers for the Marshall Islands.

B. Wandering Tattler (Heteroscelus incanus) at the underwater quarry on Enewetak island. This species was most frequently encountered, but a few birds were identified as the Greytailed Tattler (Heteroscelus brevipes) by their calls (26 March 1978).

C. Female Brown Booby (Sula leucogaster) incubating two eggs on Ribewon (James) islet (10 April 1978).

D. Black Noddy (Anous tenuirostris) guarding its chick, Ribewon islet (10 April 1978).

E. Immature Greater Frigatebirds (Fregata minor) and immature Red-footed Boobies (Sula sula) roosting together in defoliated Messerschmidia argentea trees, Ribewon islet (10 April 1978).

F. Part of the densely forested area of Ribewon islet with soaring Greater Frigatebirds (Fregata minor) (10 April 1978). 
A

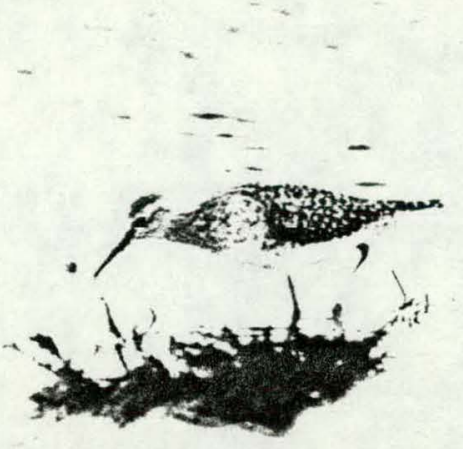

B

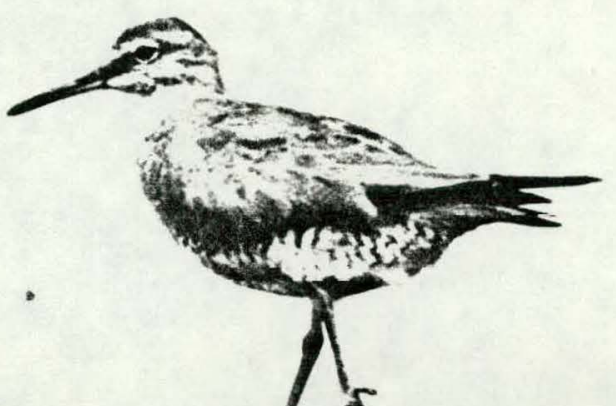

क

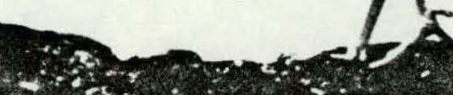

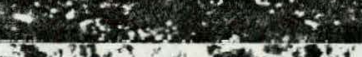

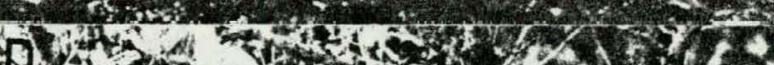

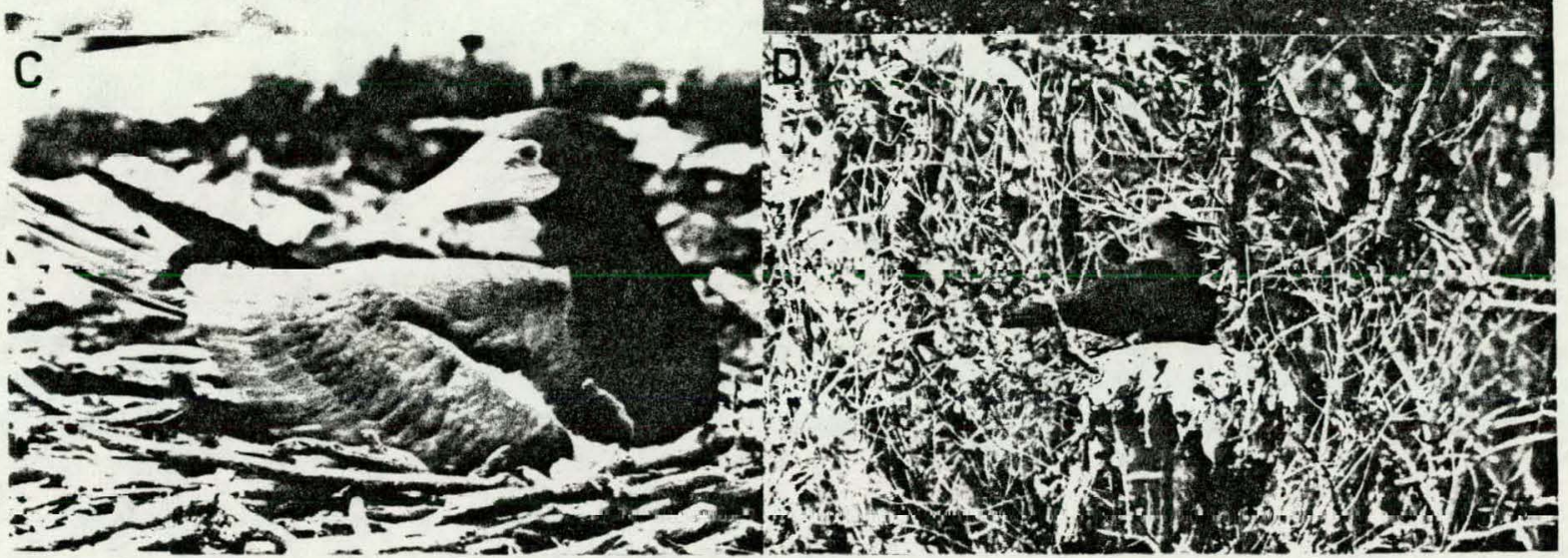

E

$F$

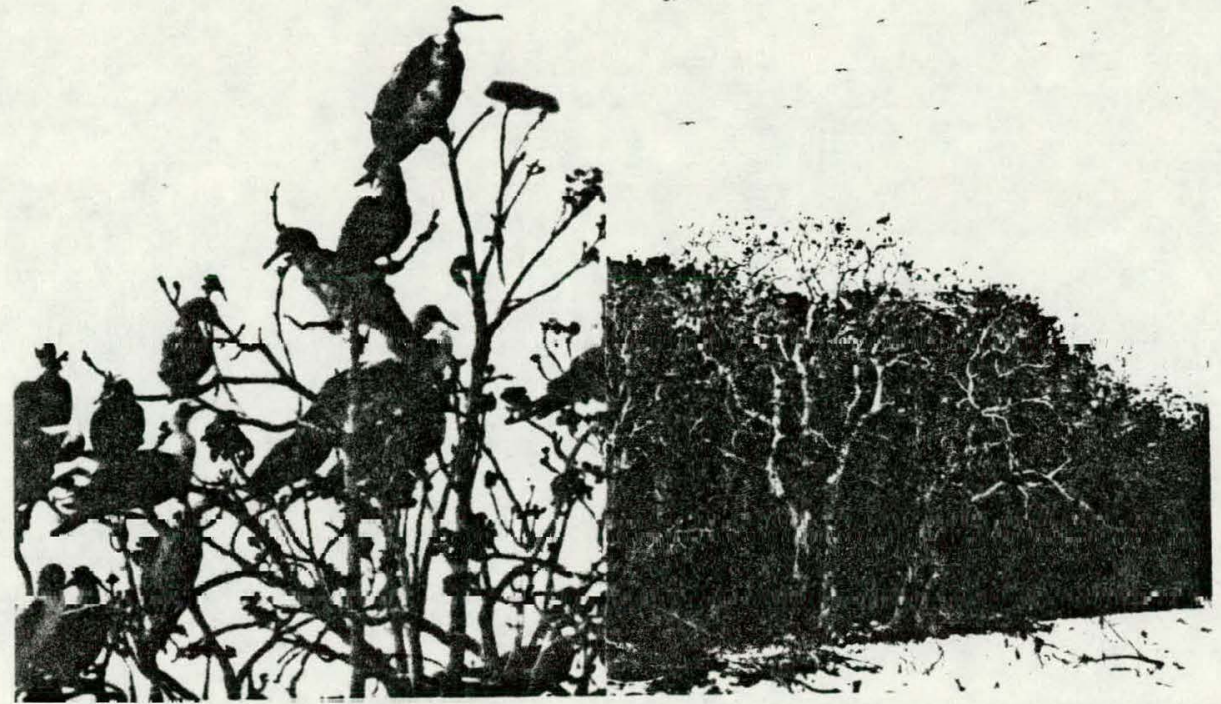


Project:

Investigators:

Objectives:
Genetic variability in "zooxanthellae" and specificity in their symbioses with reef dwelling invertebrates

Robert K. Trench

Nancy J. Colley

Department of Biological Sciences

University of California

Santa Barbara, California 93106

1. To isolate and establish cultures of the gymnodinois endosymbionts (zooxanthellae) from a variety of marine invertebrate host species.

2. To investigate the cellular and biochemical basis for recognition and specificity in these symbiotic associations.

The invertebrate hosts were collected with SCUBA at various sites in the Enewetak Lagoon. The collected animals were maintained in running seawater under local conditions of light and temperature prior to algal isolation. Table one lists the host species from which the zooxanthellae were isolated, along with sites where the species were collected.

Each host species required an isolation procedure speciflcally tailored to its morphology. The Scleractinia tissue was removed from the skeleton with a water pic; and the suspension was macerated with a blender and filtered through cheese cloth. The resultant suspension was rinsed with Millipore filtered sea water and centrifuged exhaustively to concentrate the algae and remove contaminating animal mucus and debris. The Schyphozoan oral arms were macerated in a Waring blender, filtered through cheese cloth and centrifuged exhaustively with filtered seawater. The Zoanthidea derived algae were obtained by sliting the polyp and pipetting the algae from the gastroderm, and centrifuging exhaustively.

The cultures of zooxanthellae were established by innoculating several drops of the algal suspension into $20 \mathrm{ml}$ screw top culture tubes with sterile seawater containing Provasoli's ES-1 enrichment.

These cultures were maintained under local conditions of light and temperature by placing the racks of tubes outside in the running seawater system. These cultures were combined with cultures obtained in Hawaii and transported back to our laboratories in Santa Barbara. Upon return to Santa Barbara the cultures were subsequently transferred into McLaughlin and Zahl's liquid medium, ASP-8-A, and maintained on 14:10 hour light-dark photoregime at $25^{\circ} \mathrm{C}$.

For purification of each culture, several drops were streaked onto petri dishes containing ASP-8-A, $1 \%$ agar and antibiotic solution. Subculturing in ASP-8-A without antibiotics was consequently done a week iater. Single cell clones were established by picking up individual motile cells from agar petri dishes containing several zooxanthellae. 
These axenic clonal cultures will be used for the biochemical study of the specificity in symbiotic associations between gymodinioid zooxanthellae and their reef dwelling invertebrate hosts. The zooxanthellae isolated and cultured in Enewetak will be used to investigate the cellular and biochemical basis for recognition and specificity in these symbiotic associations. The study will involve quantitative and qualitative characterizations of antigenic determinants on the cell surfaces of the cultured algae using two immunological techniques: Lectin binding and antibody binding. It will then be determined if masking of antigenic sites on the algal surfaces will inhibit uptake of the algae by a given test host. The morphological modifications which occur on the algal surfaces following host infection will be monitored using electron microscopy.

Table 1

Host

Onidaria (phylum)

Scyphozoa (class

Mastigias ocellatus

Anthozoa (class)

Xenia sp.

Zoantharia (subclass)

Zoanthiniaria (order)

Zoanthus sp.

Scleractinia (order)

Achrillia horrsecens

Eavia sp.

Fungia scutaria

Fungia scutaria

Herpolitha limax

Herpolitha limax

Lobophyzlia sp.

Pavona praetorta

Pavona praetoria

Pocillipora damicomis

Pocillipora meandrina

Porites lobata

Porites convexa (=Hawaiiensis)

Porites convexa

Acropora nasuta

Mollusca (phylum)

Pelecypoda (class)

Tridacna maxima

Tridacna squamosa
Location

Date Isolated

Alice

$8 / 24 / 78$

MAC terminal reef

$8 / 23 / 78$

MAC terminal reef

$8 / 28 / 78$

MAC terminal reef

$8 / 28 / 78$

Jinimi, lagoon reef

$8 / 27 / 78$

Jinimi, lagoon reef

$8 / 15 / 78$

MAC terminal reef

$8 / 27 / 78$

Jinimi, lagoon reef

$8 / 15 / 78$

MAC terminal reef

$8 / 27 / 78$

Jinimi, lagoon reef

$8 / 26 / 78$

Jinimi, lagoon reef

$8 / 12 / 78$

Medren

$8 / 18 / 78$

Jinimi, lagoon reef

$8 / 22 / 78$

MAC terminal reef

$8 / 26 / 78$

Outside quarry

$8 / 25 / 78$

$8 / 15 / 78$

$8 / 26 / 78$

MAC terminal reef

$8 / 15 / 78$

Between Medren and Sand Is.

Jinimi, lagoon reef

Jinimi, ocean side 70 feet

$8 / 11 / 78$

$8 / 23 / 78$ 
Project: Patterns in growth and mortality of marine gastropods at Enewetak Atoll

Investigator: Ted R. Turk

Department of Biology.

San Diego State University

San Diego, California 92182

Objectives: 1 . To determine growth and mortality rates of several co-occurring snail species.

2. To study the relationship of growth rate to mortality rate.

3. To study the relationship of growth and mortality to other factors, such as recruitment rate and physical factors.

4. To compare differences in life history features between tropical and temperature species.

The study area is an intertidal trough on the southeastern part of Ananij Island. On previous visits to MPML the following numbers of animals were marked and released: Thais aculeata.(Sept. 1976 and Feb. 1977, total of 706 marked); Vasum turbineZlus (Sept. 1976 and Feb. 1977, total of 1,008 marked); Conus ebraeus (Feb. and Sept. 1977, total of 1,095 marked); Conus sponsalis (Feb. and Sept. 1977, total of 636 marked); Morula granulata (Feb. and Sept. 1977, total of 713 marked); Dmupa ricina (Sept. 1977, total of 623 marked); and Drupa momum (Sept. 1977, total of 571 marked).

On this trip the following numbers of animals were collected: 327 Thais (10 marked); 623 Vasum (13 marked); 577 Conus ebraeus (16 marked); 373 C. sponsalis (7 marked); 371 Morula (3 marked); 636 Drupa ricina (5 marked); and 5.7. D. morum (6 marked). A probable reason for the small number of recaptures is too long of an elapsed time between marking dates and the current collection resulting in a high rate of shell fouling. Most of the marked individuals reported here were identified only after tedious abrading and examination. Other factors are the large population sizes and high rates of movement.

The resulting size distributions, and estimates of parameters $S_{\infty}$ (maximum size) and $\mathrm{K}$ (rate of approach to maximum size) from the Bertalanffy growth equation and using the measurement of marked individuals, are attached and can be compared to those in previous reports. 
84

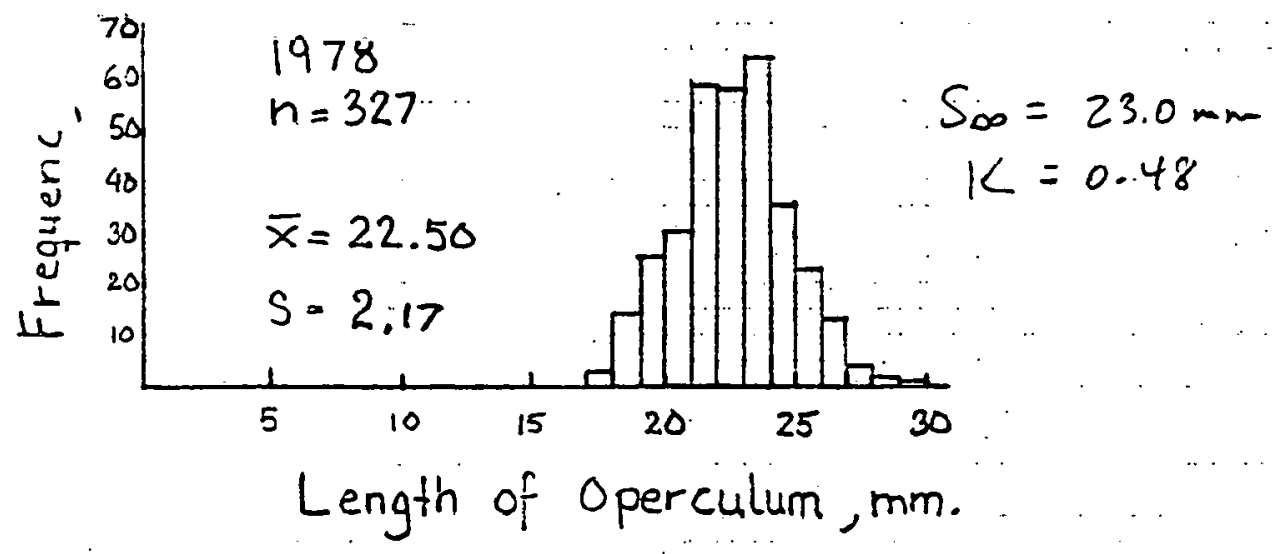

Fig. I. Thais aculeata

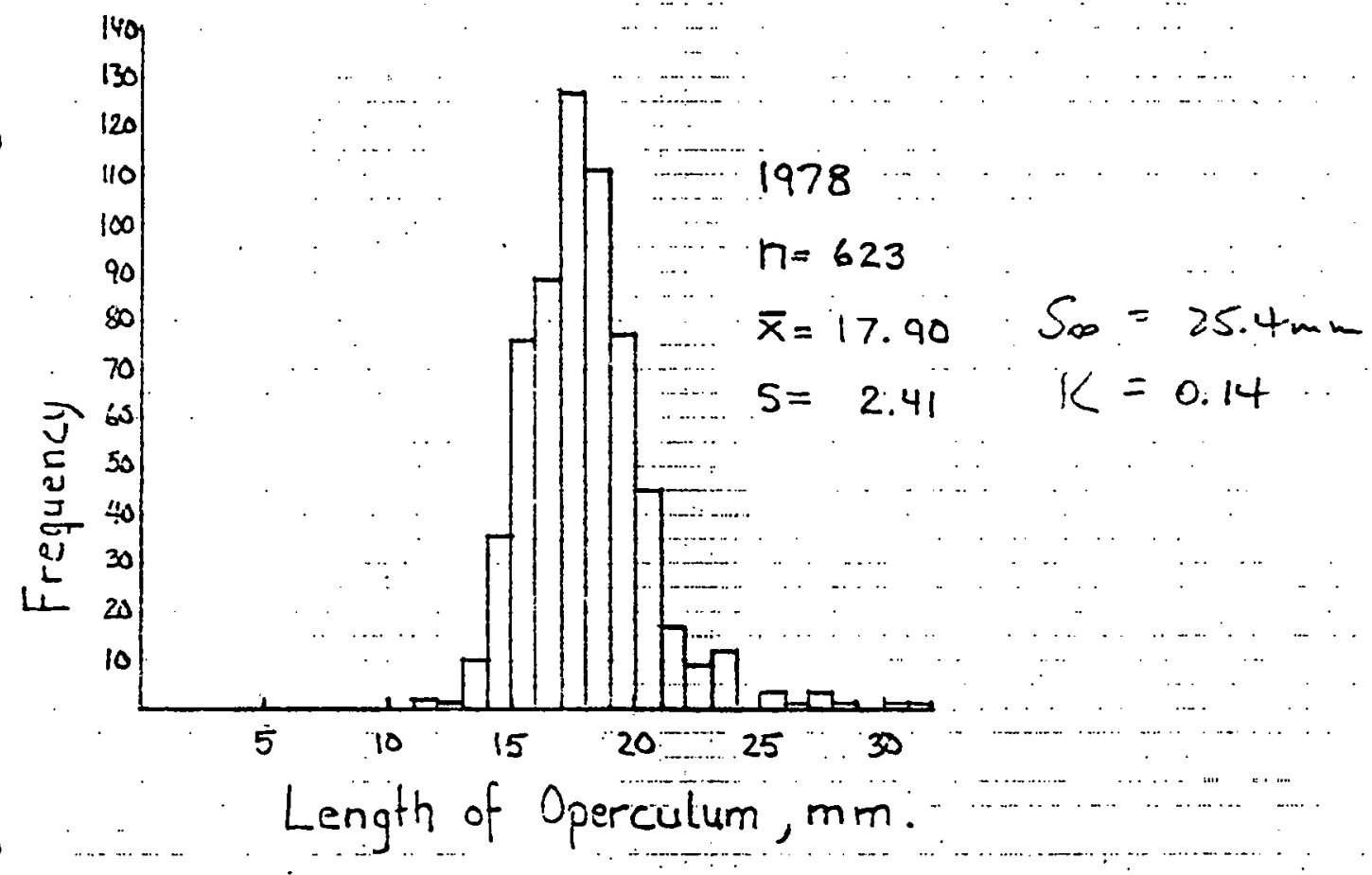

Fig 2: Vasum turbinellus 
85

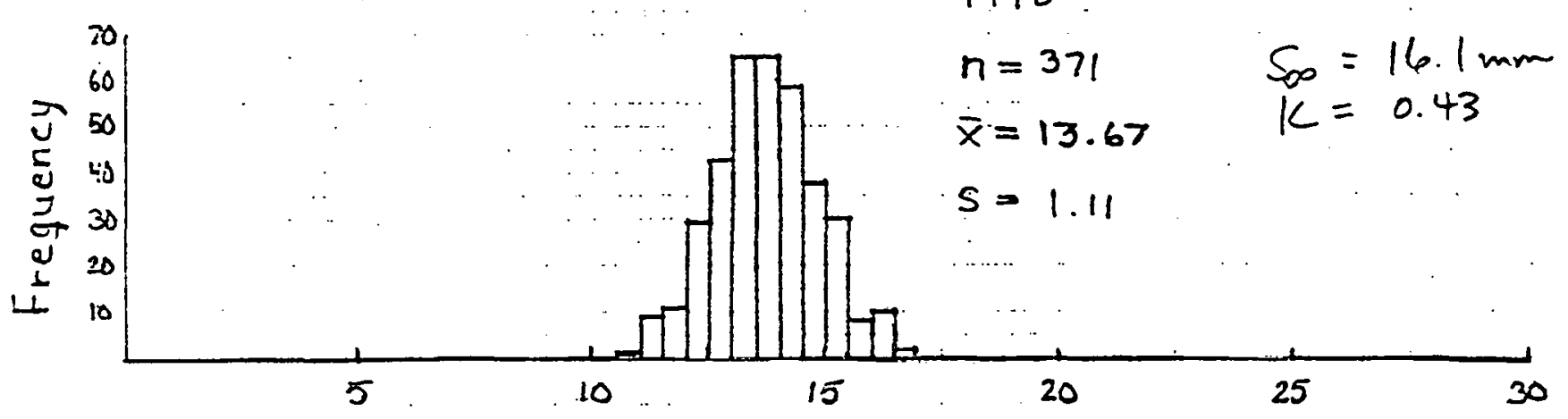

Length of Operculum, $\mathrm{mm}$.

Fig 3. Morula granulate

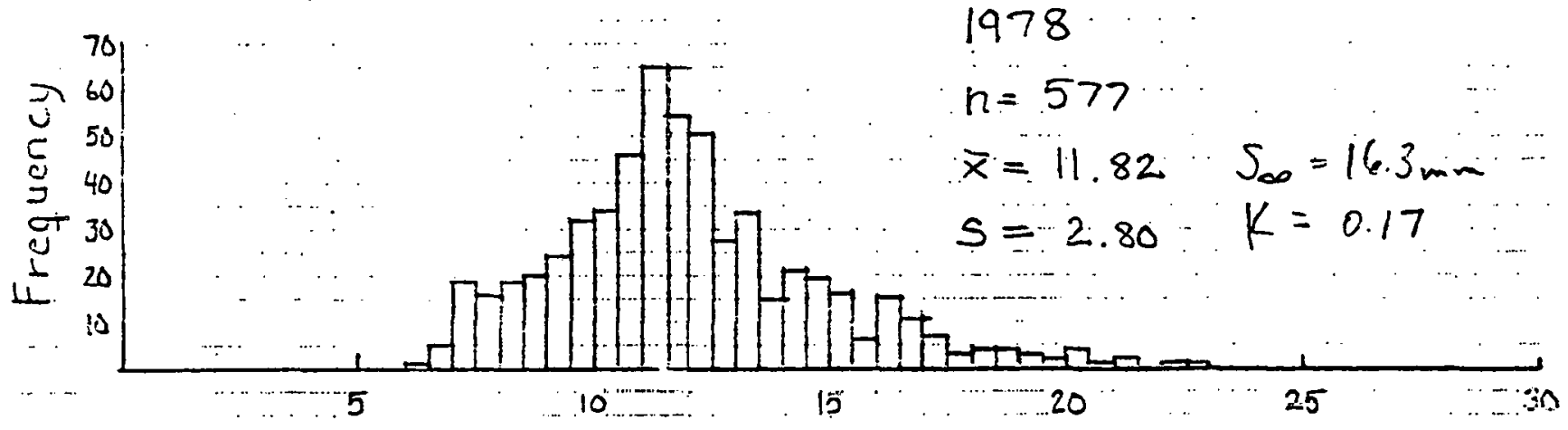

Length of Operculum, $\mathrm{mm}$

Fig 4. Cornus ebraeus 

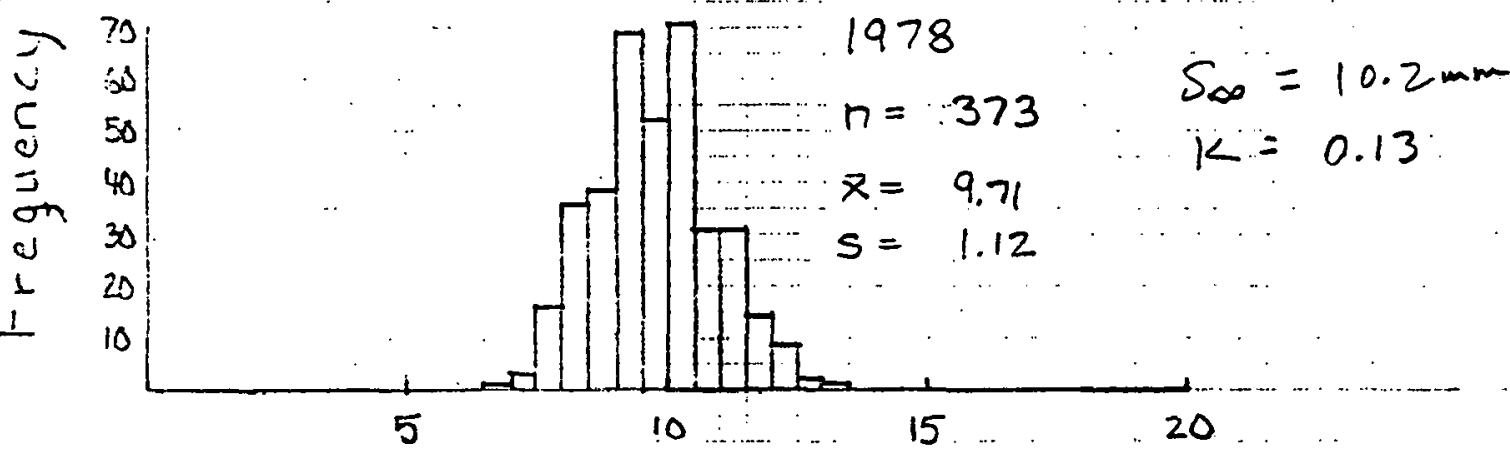

Length of Operculum, $\mathrm{mm}$.

Fig. 5. Conus sponsalis

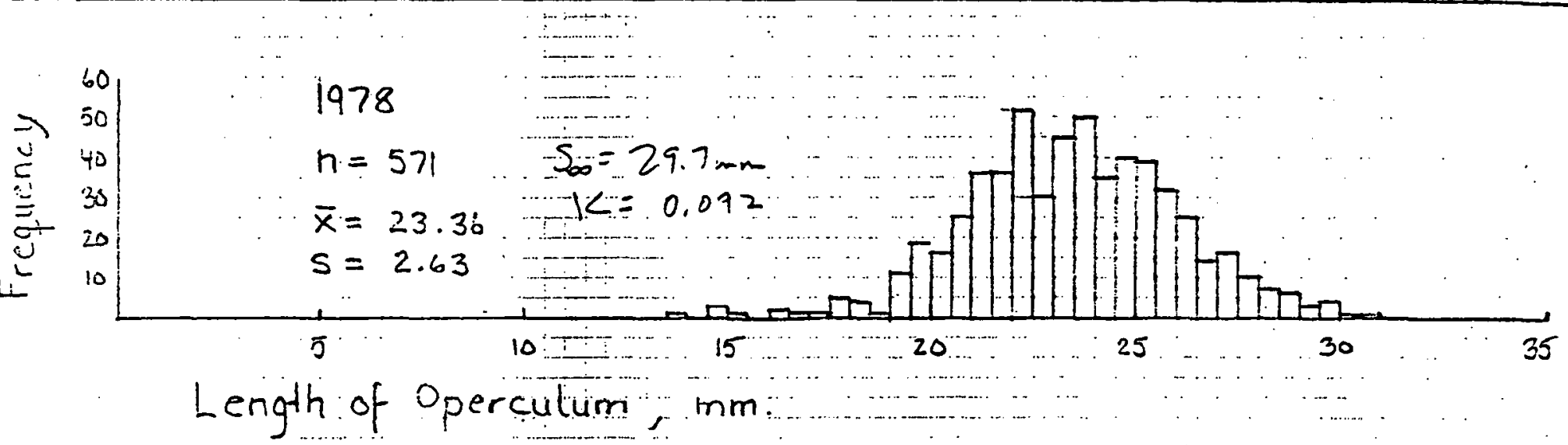

Figb. Drupa morum

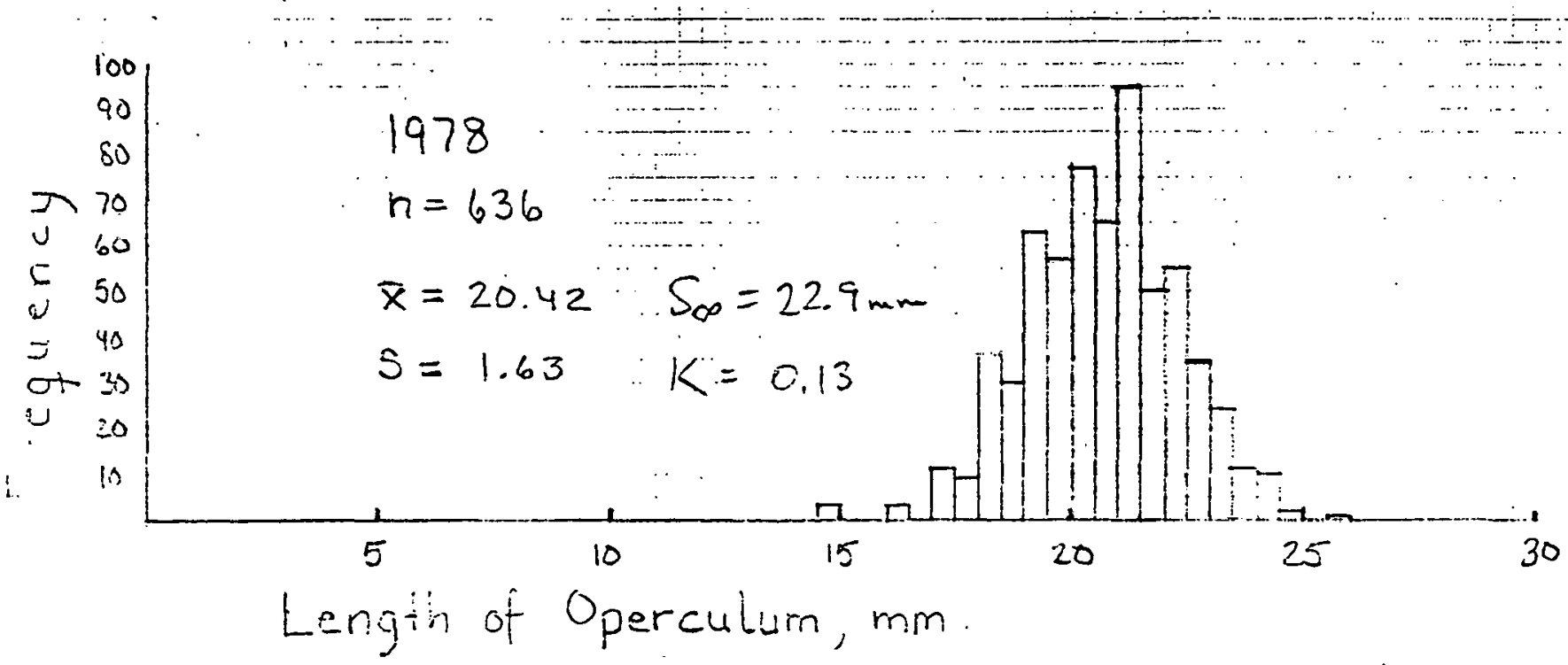

Fio, 7. Druoo ricina 
Department of Energy

Technical Information Ctr.

Department of Energy

Nevada Technical Library

Dr. Helen M. McCammon。 Senior Oceanographer

Mr. Roger Ray

Asst. for Pacific Operations

Department of Energy

Pacific Area Support Ofc.

Office of Research Admin.

Director

Hawaii Institute of

Marine Biology

Director

Mid-Pacific Marine Lab.

Manager

Mid-Pacific Marine Lab.

Director

Research Corporation of the Univ. of Hawaii

Dr. Ernst S. Reese

Dr. Robert. W. Buddemeier

Dr. Stephen V. Smith
P. 0. Box 62

Oak Ridge, TN 37830

Nevada Operations office

P. 0. Box 14100

Las Vegas, NV 89114

U. S. Department of Energy

Div. of Biomedical \& Environ Research

Washington, D. C. 20545

Nevada Operations Office

P. 0. Box 14100

Las Vegas; NV 89114

P. O. Box 29939

Honolulu, HI 96820

University of Hawaii

2

Honolulu, HI 96822

P. O. Box 1346

Kaneohe, HI 96744

Hawaii Institute of Marine Biology

P. 0. Box 1346

Kaneohe, HI 96744

Enewetak Atoll

Marshall Islands 96737

2

1110 University Avenue

Honolulu, HI 96826

Hawaii Institute of Marine Biology P. 0. Box 1346

Raneohe, HI 96744

Department of Oceanography University of Hawaii Honolulu, HI 96822

Hawail Institute of Mar1ne Blology P. 0. Box 1346

Kaneohe, HI 96744 